National Marine

Fisheries Service

NOAA
Fishery Bulletin

a established in 1881 a
Spencer F. Baird

First U.S. Commissione of Fisheries and founder of Fishery Bulletin
Abstract-Age-0 winter flounder (Pseudopleuronectes americanus; 20$90 \mathrm{~mm}$ in total length [TL]) and summer flounder (Paralichthys dentatus; 19-172 mm TL) were collected from the Seekonk and Taunton Rivers (in Rhode Island and Massachusetts, respectively) from May through September during 2009-2015, and stomach content analysis was used to assess diet composition and resource overlap for these species. Winter and summer flounder underwent ontogenetic dietary shifts. Winter flounder $<40 \mathrm{~mm}$ TL predominantly fed on copepods, transitioning to amphipods, isopods, and bivalves with increasing size. Polychaetes also were consumed frequently by winter flounder, irrespective of size. The principal prey of summer flounder $<60 \mathrm{~mm}$ TL were mysid shrimp and copepods, whereas sand shrimp (Crangon septemspinosa), amphipods, and fish were the dominant prey of larger conspecifics. There was minimal dietary overlap for the flounder species when comparisons were made independent of body size, indicating food niche segregation. For winter and summer flounder of equivalent sizes, however, dietary overlap was inversely related to TL. Moderate to high resource overlap occurred for small winter and summer flounder $(<40 \mathrm{~mm}$ TL) and was attributed to their mutual reliance on copepods and amphipods. Despite evidence of dietary overlap, it is unlikely that shared prey resources were diminished enough to negatively affect either flounder species.

Manuscript submitted 7 June 2016. Manuscript accepted 20 December 2016. Fish. Bull. 115: 167-185 (2017).

Online publication date: 2 February 2017. doi: $10.7755 /$ FB.115.2.4

The views and opinions expressed or implied in this article are those of the author (or authors) and do not necessarily reflect the position of the National Marine Fisheries Service, NOAA.

\title{
Feeding habits and dietary overlap of age-0 winter flounder (Pseudopleuronectes americanus) and summer flounder (Paralichthys dentatus) in southern New England tidal rivers
}

\author{
David L. Taylor (contact author) \\ Carissa L. Gervasi \\ Email address for contact author: dtaylor@rwu.edu \\ Department of Marine Biology \\ Roger Williams University \\ One Old Ferry Road \\ Bristol, Rhode Island 02809
}

The winter flounder (Pseudopleuronectes americanus) is a pleuronectid flatfish that inhabits northwest and mid-Atlantic waters from Nova Scotia southward to Maryland (Pereira et al., 1999). Winter flounder have traditionally supported valuable commercial and recreational fisheries within this geographic range, and, in the United States, this species is managed as 3 discrete stocks in the following areas: southern New England and Middle-Atlantic (SNE-MA), Gulf of Maine, and Georges Bank. There are ongoing concerns with respect to the SNE-MA stock complex because populations of winter flounder have decreased precipitously since the early 1980s and have not rebounded over the last 3 decades (NEFSC ${ }^{1,2}$ ). Although overexploitation was paramount in their initial population decline $\left(\mathrm{NEFSC}^{2}\right)$, other hypotheses have been purported to explain the failed recovery of winter

${ }^{1}$ NEFSC (Northeast Fisheries Science Center).2011. 52 $2^{\text {nd }}$ Northeast regional stock assessment workshop (52 $2^{\text {nd }}$ SAW) assessment report. U.S. Dep. Commer., Northeast Fish. Sci. Cent. Ref. Doc. 1117, 962 p. [Available from website.]

2 NEFSC (Northeast Fisheries Science Center). 2015. Operational assessment of 20 Northeast groundfish stocks, updated through 2014. U.S. Dep. Commer., Northeast Fish. Sci. Cent. Ref. Doc. 15-24, 251 p. [Available from website.] flounder in southern New England (e.g., the Narragansett Bay Estuary in Rhode Island and Massachusetts) (Collie et al., 2008). These hypotheses include a complex suite of abiotic (temperature) and biotic (predation and resource competition) factors that affect the survival of winter flounder during early development (Keller and Klein-MacPhee, 2000; DeLong et al., 2001; Taylor and Collie, 2003a, 2003b).

Coastal populations of winter flounder spawn demersal eggs inside estuaries during the winter and early spring (Pearcy, 1962). Larval winter flounder hatch 14-21 days after spawning and are pelagic for $\sim 60$ days (Chambers and Leggett, 1987), after which they metamorphose into benthic juveniles during the late spring and early summer (Pearcy, 1962). By virtue of adults spawning at cold temperatures $\left(2-5^{\circ} \mathrm{C}\right)$, pelagic larvae benefit from reduced competition with other species (Jeffries and Terceiro, 1985). After metamorphosis, however, inter- and intraspecific competition among juvenile winter flounder may be greatly enhanced (Karlson et al., 2007; Nissling et al., 2007; Złoch and Sapota, 2010; Ustups et al., 2016). For example, juvenile winter flounder are often confined to specific depth ranges, have relatively low mobility, and possess more ob- 

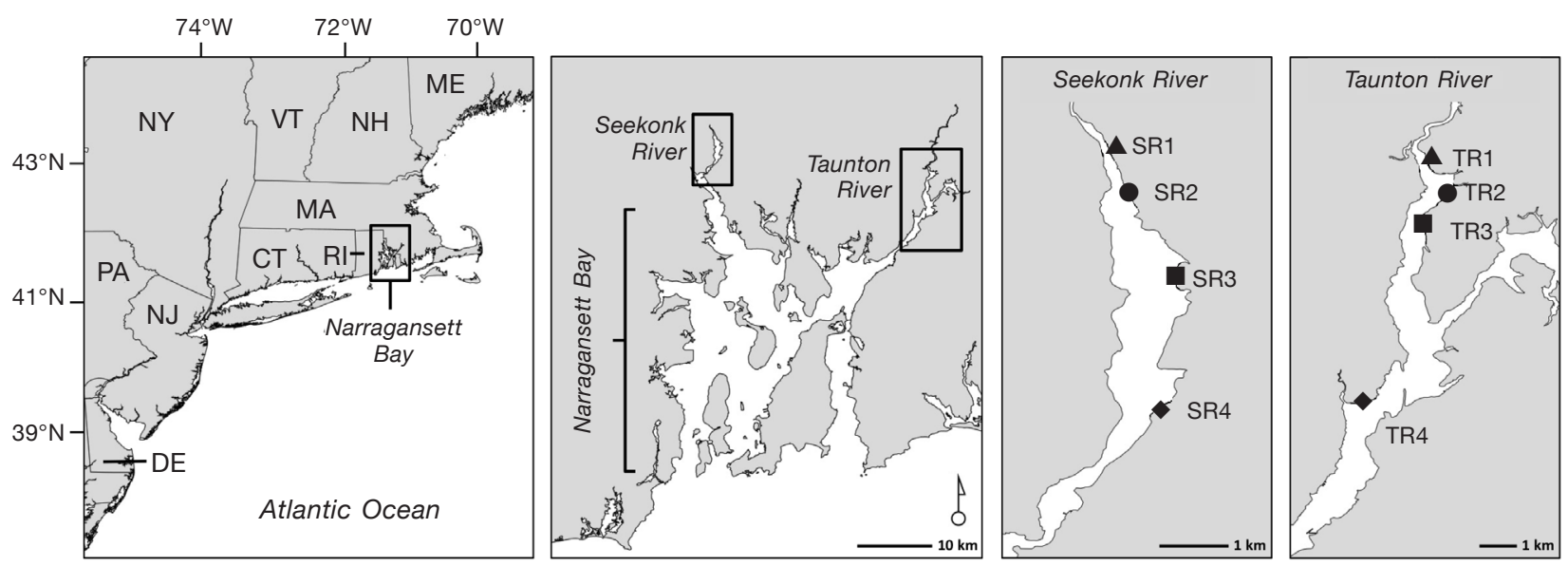

Figure 1

Map of the Seekonk River (SR) and Taunton River (TR), in Rhode Island and Massachusetts, respectively, with points denoting collection sites for age-0 winter flounder (Pseudopleuronectes americanus) and summer flounder (Paralichthys dentatus). Four sites were sampled fortnightly in each river (SR1-SR4; TR1-TR4) from May through September 2009-2015, with the exception of SR1, which was not surveyed in 2014, and SR3 and TR3, which were not surveyed in 2012-2015.

vious habitat requirements than pelagic fish (Bailey, 1994). The transition in habitat use after metamorphosis and subsequent changes in biotic interactions may be critical in determining their recruitment success and year-class strength.

The summer flounder (Paralichthys dentatus) is a paralichthid flatfish that supports lucrative fisheries throughout its geographic range; adults mainly occupy estuarine and inner continental shelf waters in the Mid-Atlantic Bight from Massachusetts to North Carolina (Packer et al., 1999). Summer flounder spawn pelagic eggs on the continental shelf during the fall and early winter, and peak spawning activity occurs in October and November (Packer et al., 1999). Eggs of summer flounder hatch $\sim 3$ days after spawning, after which planktonic larvae recruit to inshore nurseries from October through May and subsequently transition to the benthic juvenile life stage.

The distribution of juvenile summer flounder reportedly was limited to inshore nurseries between New Jersey and North Carolina (Able and Kaiser ${ }^{3}$ )—a range that was delineated at its northern extent by the increased sensitivity of early-stage summer flounder to cold water temperatures $\left(<2^{\circ} \mathrm{C}\right.$; Malloy and Targett, 1991). Taylor et al. (2016), however, recently documented a northward shift in the distribution of juvenile (age-0) summer flounder and their use of southern New England nurseries, including the Narragansett Bay and associated tidal rivers. Juvenile summer flounder, therefore, have a geographic range that extends farther north than previously recognized. Moreover, the northward expansion of juvenile summer flounder is attributed to elevated coastal water temperatures in

\footnotetext{
${ }^{3}$ Able, K. W., and S. C. Kaiser. 1994. Synthesis of summer flounder habitat parameters. NOAA Coast. Ocean Program, Decis. Anal. Ser. 1, 68 p. NOAA Coastal Ocean Office, Silver Spring, MD.
}

the northwest Atlantic (Smith et al., 2010; Taylor et al., 2016), where warmer temperatures affect the distribution of the adult spawning stock (Nye et al., 2009) and overwintering survival of age-0 summer flounder spawned the previous fall (Malloy and Targett, 1991).

The increased abundance of juvenile summer flounder in southern New England nurseries may have important consequences for resident populations of winter flounder. Foremost, the spatial and temporal overlap of species could increase interspecific dietary overlap and potential competitive interactions in New England coastal habitats (e.g., tidal rivers) (Taylor et al., 2016). To date, the diet composition and foraging ecology of juvenile winter and summer flounder has not been examined in this geographic area or habitat-type. Therefore, the main objective of this study was to evaluate the feeding habits and putative biotic interactions between age- 0 winter and summer flounder collected from the Seekonk and Taunton Rivers (in Rhode Island and Massachusetts, respectively): 2 tidal rivers that are contiguous with Narragansett Bay and serve as important nursery habitat for both species (Taylor et al., 2016). Conventional stomach-content analysis was used to explore ontogenetic and spatiotemporal variations in intraspecific diet composition and foraging ecology. Direct visual analysis of food habits and complementary diet indices were also used to assess the extent of dietary overlap of the focal species.

\section{Materials and methods}

\section{Field sampling}

Age-0 winter flounder and summer flounder were collected from May through September during 2009-2015 from the Seekonk and Taunton Rivers (Fig. 1). Each 


\section{Table 1}

Summary of environmental and biological characteristics at individual sites in the Seekonk River (SR) and Taunton River (TR) in Rhode Island and Massachusetts, respectively, where winter flounder (Pseudopleuronectes americanus) and summer flounder (Paralichthys dentatus) were collected during 2009-2015. Values represent annual means, with standard errors (SEs), and ranges of measurements taken per sampling effort across months (May-September). Environmental data include water temperature $\left({ }^{\circ} \mathrm{C}\right)$, salinity, and dissolved oxygen $(\mathrm{mg} / \mathrm{L})$, and biological data include abundance (individuals $/ 100 \mathrm{~m}^{2}$ ) and "fresh" (i.e., measured immediately after capture) total length ( $\mathrm{mm}$ ) of winter flounder (WF) and summer flounder (SF).

\begin{tabular}{|c|c|c|c|c|c|c|c|c|}
\hline \multirow[b]{2}{*}{ Site } & \multicolumn{4}{|c|}{ Seekonk River } & \multicolumn{4}{|c|}{ Taunton River } \\
\hline & SR1 & SR2 & SR3 & SR4 & TR1 & TR2 & TR3 & TR4 \\
\hline \multicolumn{9}{|c|}{ Environmental characteristics } \\
\hline \multicolumn{9}{|c|}{ Temperature } \\
\hline Mean & $22.9(\mathrm{SE} 1.1)$ & $23.5(\mathrm{SE} 1.2)$ & $23.6(\mathrm{SE} 1.3)$ & $23.2(\mathrm{SE} 1.1)$ & $23.0(\mathrm{SE} 1.3)$ & $23.5(\mathrm{SE} 1.4)$ & $22.8(\mathrm{SE} 1.5)$ & $22.9(\mathrm{SE} 1.4)$ \\
\hline Range & $19.0-26.8$ & $19.5-27.8$ & $17.6-28.4$ & $19.4-26.8$ & $17.8-26.8$ & $18.1-26.9$ & $17.9-24.9$ & $17.7-26.5$ \\
\hline \multicolumn{9}{|l|}{ Salinity } \\
\hline Mean & 5.0 (SE 1.3) & 7.2 (SE 1.7) & $8.3(\mathrm{SE} 1.5)$ & $10.7(\mathrm{SE} 2.0)$ & $3.2(\mathrm{SE} 1.1)$ & 8.9 (SE 1.7) & $7.4(\mathrm{SE} 1.3)$ & $19.5(\mathrm{SE} 1.6)$ \\
\hline Range & $1.7-10.6$ & $2.8-13.8$ & $3.3-14.1$ & $4.3-18.0$ & $0.3-7.4$ & $3.6-15.6$ & $4.2-10.2$ & $12.3-24.0$ \\
\hline \multicolumn{9}{|c|}{ Dissolved oxygen } \\
\hline Mean & $7.2(\mathrm{SE} 0.8)$ & 7.5 (SE 0.7) & $8.8(\mathrm{SE} 1.0)$ & $8.5(\mathrm{SE} 0.8)$ & $6.5(\mathrm{SE} 0.5)$ & $7.1(\mathrm{SE} 0.6)$ & $7.7(\mathrm{SE} 0.6)$ & $6.8(\mathrm{SE} 0.6)$ \\
\hline Range & $4.4-9.9$ & $4.7-9.7$ & $5.0-12.3$ & $5.9-10.9$ & $4.7-8.1$ & $5.2-9.7$ & $6.3-9.1$ & $4.8-9.1$ \\
\hline \multicolumn{9}{|c|}{ Biological characteristics } \\
\hline \multicolumn{9}{|c|}{ WF abundance } \\
\hline Mean & $92.4(\mathrm{SE} 44.4)$ & $42.8(\mathrm{SE} 22.2)$ & 6.8 (SE 4.2) & $16.2(\mathrm{SE} 5.8)$ & 1.6 (SE 0.7) & $5.1(\mathrm{SE} 2.3)$ & $2.4(\mathrm{SE} 0.3)$ & $7.3(\mathrm{SE} 3.0)$ \\
\hline Range & $5.6-286.1$ & $2.4-136.2$ & $0.0-26.8$ & $4.8-42.4$ & $0.06-4.3$ & $1.2-16.5$ & $2.0-3.4$ & $1.5-21.8$ \\
\hline \multicolumn{9}{|c|}{ WF total length } \\
\hline Mean & $52.6(\mathrm{SE} 4.7)$ & 49.7 (SE 3.9) & $49.2(\mathrm{SE} 3.3)$ & $54.5(\mathrm{SE} 3.0)$ & $64.5(\mathrm{SE} 3.4)$ & $52.7(\mathrm{SE} 4.5)$ & $55.2(\mathrm{SE} 5.0)$ & $53.9(\mathrm{SE} 2.5)$ \\
\hline Range & $26.9-85.0$ & $26.4-76.3$ & $34.8-70.2$ & $32.8-75.0$ & $23.0-87.0$ & $28.4-77.2$ & $27.5-85.2$ & $37.8-70.8$ \\
\hline \multicolumn{9}{|c|}{ SF abundance } \\
\hline Mean & $10.5(\mathrm{SE} 4.7)$ & $5.7(\mathrm{SE} 3.6)$ & $5.5(\mathrm{SE} 3.8)$ & $3.2(\mathrm{SE} 2.2)$ & $1.0(\mathrm{SE} 0.6)$ & $2.1(\mathrm{SE} 1.2)$ & 1.7 (SE 0.7) & $0.05(\mathrm{SE} 0.04)$ \\
\hline Range & $1.7-33.2$ & $0.08-24.5$ & $0.0-23.6$ & $0.06-14.3$ & $0.2-3.8$ & $0.1-7.8$ & $0.3-2.8$ & $0.0-0.3$ \\
\hline \multicolumn{9}{|c|}{ SF total length } \\
\hline Mean & $80.4(\mathrm{SE} 12.0)$ & $84.3(\mathrm{SE}$ 13.3) & 65.7 (SE 3.6) & 77.7 (SE 11.2) & 88.9 (SE 14.9) & ) 91.1 (SE 12.1) & ) $97.8(\mathrm{SE} 6.9)$ & $105.2(\mathrm{SE} 12.0)$ \\
\hline Range & $31.1-155.0$ & $32.2-160.0$ & $47.7-71.0$ & $32.0-133.0$ & $37.0-137.0$ & $40.3-236.0$ & $75.4-126.0$ & $69.0-118.9$ \\
\hline
\end{tabular}

year, 3-4 sites per river were sampled fortnightly with a beach-seine set that was $15 \times 1.8 \mathrm{~m}$ in width (and had $0.64-\mathrm{cm}$ mesh size and $0.48-\mathrm{cm}$ mesh size in the bunt). Sampling occurred during daylight ( 0800-1600; \pm 2 $\mathrm{h}$ of low tide), and 1 haul was conducted per site per date. Winter and summer flounder captured during field sampling were counted immediately (number per 100 square meters; Taylor et al., 2016) and measured to the nearest millimeter for "fresh" total length (TL) (Table 1, Fig. 2). For each sampling effort, $\leq 10$ individuals of each flounder species in a random subsample were preserved in $70 \%$ ethanol for subsequent stomach content analysis, and remaining individuals were returned to their place of capture. Surface temperature (degrees Celsius), salinity, and dissolved oxygen (milligrams per liter) were also measured at each site per date with a handheld YSI Model $85^{4}$ meter (YSI Inc., Yellow Springs, OH). The environmental conditions and

\footnotetext{
${ }^{4}$ Mention of trade names or commercial companies is for identification purposes only and does not imply endorsement by the National Marine Fisheries Service, NOAA.
}

biological data for winter and summer flounder across the sampling sites are summarized in Table 1.

\section{Stomach content analysis}

In the laboratory, winter and summer flounder previously preserved in $70 \%$ ethanol were measured for "preserved" TL (in millimeters). Prey were then extracted from fish stomachs and identified to the lowest practical taxon by using stereoscopic microscopes. The contribution of each prey taxon to the diet of winter and summer flounder was expressed by 3 component indices (Hyslop, 1980): frequency of occurrence $(\% F)$, volumetric percentage $(\% \mathrm{~V})$, and numeric percentage $(\% N)$, where $\% F$ equaled the number of stomachs containing a specific prey taxon divided by the total number of stomachs with food contents (a nonadditive index), $\% V$ was the visual determination of the volumetric contribution of a prey taxon to the total stomach volume of a winter or summer flounder, and $\% \mathrm{~N}$ was the number of individuals within a prey taxon divided by the total number of prey identified in a stomach of a winter or summer flounder. 


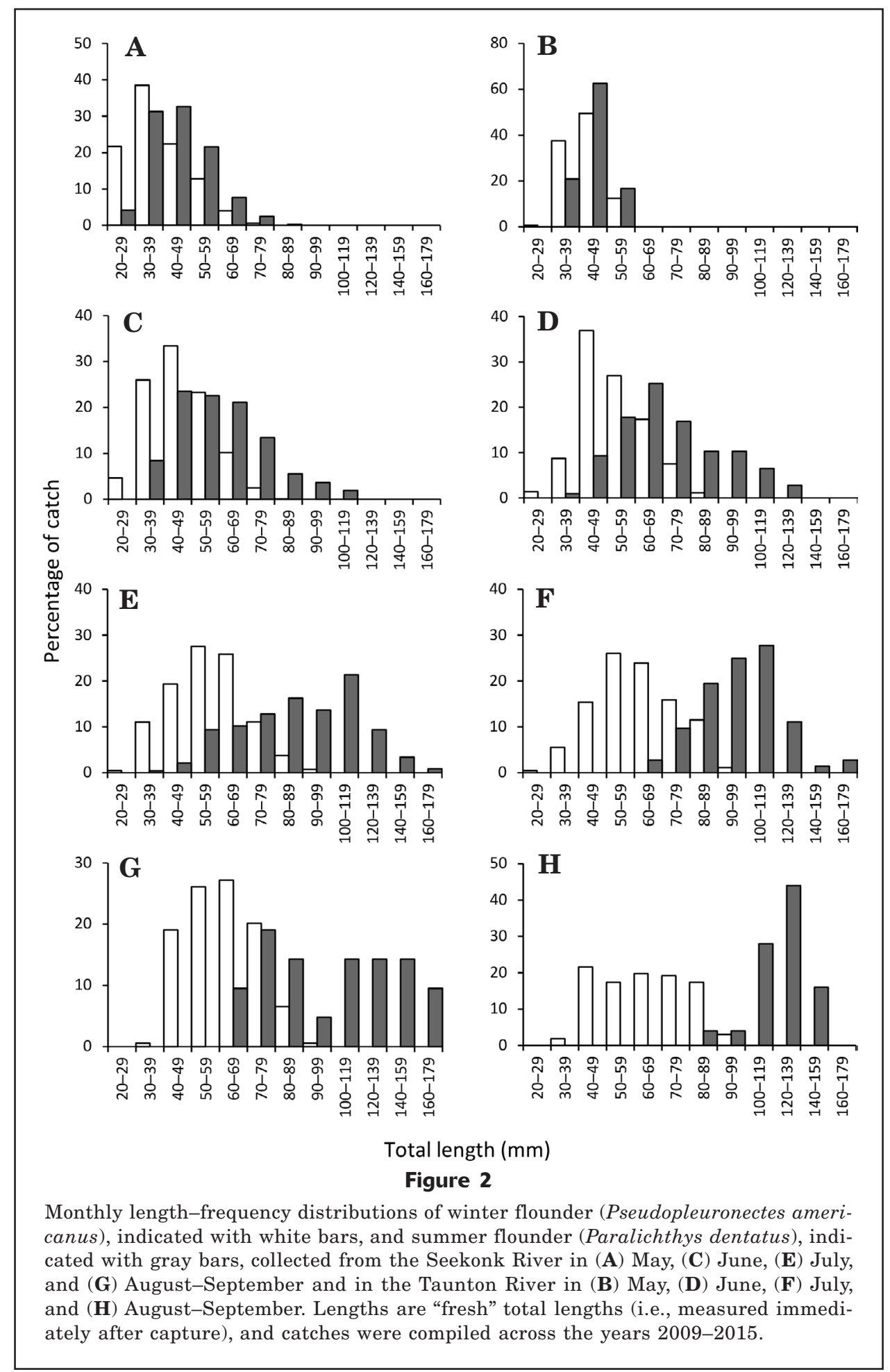

It is important to note that numerical counts are potentially problematic for soft-bodied prey because mastication of one dietary item could result in multiple countable parts. Accordingly, for soft-body prey, conservative estimates of $\% N$ were made by counting distinct body features (e.g., counts for polychaetes were typi- cally limited to head and posterior segments, including distinctive tentacles, palps, proboscises, jaws, or cirri). Moreover, when present in the stomach of a winter or summer flounder, a numerical count of 1 was recorded for food items that occurred in nondiscrete units (i.e., detritus; Hyslop, 1980). 
The percent index of relative importance (\%IRI) was used to estimate the overall contribution of a prey taxon to the diet of winter and summer flounder, such that

$$
\% I R I_{\mathrm{k}}=\frac{I R I_{\mathrm{k}}}{\sum_{k=1}^{n_{p}} I R I_{\mathrm{k}}} \times 100,
$$

where $\% I R I_{\mathrm{k}}=$ a compound index calculated for prey taxon $k$ and equal to $\left(\% N_{\mathrm{k}}+\% V_{\mathrm{k}}\right) \times \% F_{\mathrm{k}}$; and $n_{\mathrm{p}}=$ the total number of prey taxa identified in stomachs of winter and summer flounder ( $n_{\mathrm{p}}$ : 33 and 32 , respectively).

The IRI index was selected as a descriptor of the diet of winter and summer flounder in this study for 2 principal reasons: 1) to minimize biases associated with individual component indices (Hyslop, 1980; Cortés, 1997; Liao et al., 2001; Hart et al., 2002), although others have noted that compound indices may exacerbate the error term and are affected by the taxonomic resolution of prey (Hyslop 1980; Hansson, 1998), and 2) to facilitate comparisons with other studies of juvenile flounder diet that have a similar approach (Burke, 1995; Carlson et al., 1997; Grover, 1998; Złoch and Sapota, 2010; Sagarese et al., 2011).

Lastly, each seine haul yielded a cluster of winter and summer flounder, and these individuals likely have increased similarities in diet relative to conspecifics sampled at different sites or dates (Bogstad et al., 1995). As such, the aforementioned component and compound diet indices (by percentages) were recalculated by using a cluster sampling estimator (Buckel et al., 1999; Latour et al., 2008), and these data were used in all subsequent analyses (e.g., hierarchical cluster and permutational multivariate analyses; see "Intraspecific dietary analysis" section). The cluster sampling estimator is represented as

$$
\% X_{\mathrm{k}}=\frac{\sum_{i=1}^{n_{\mathrm{c}}} M_{\mathrm{i}} q_{\mathrm{ik}}}{\sum_{i=1}^{n_{\mathrm{c}}} M_{\mathrm{i}}} \times 100,
$$

where $q_{\mathrm{ik}}=\frac{x_{\mathrm{ik}}}{x_{\mathrm{i}}}$,

$\% X_{\mathrm{k}}=$ one of several diet indices $(\% F, \% N, \% \mathrm{~V}$, or $\% I R I)$ for prey taxon $k$;

$n_{\mathrm{c}}=$ the number of clusters (e.g., number of seine hauls containing winter or summer flounder);

$M_{\mathrm{i}}=$ the number of winter or summer flounder collected from site $i$ on a specific date;

$x_{\mathrm{i}}=$ the total frequency, number, volume, or index of relative importance of all prey in the stomachs of winter or summer flounder collected from site $i$; and

$x_{\mathrm{ik}}=$ the total frequency, number, volume, or index of relative importance of prey taxon $k$ in flounder stomachs from site $i$.

The variance estimate for $\% X_{\mathrm{k}}$ was calculated as

$$
\operatorname{var}\left(\% X_{\mathrm{k}}\right)=\frac{1}{n_{\mathrm{c}} \overline{M^{2}}} \frac{\sum_{i=1}^{n_{\mathrm{c}}} M_{i}^{2}\left(q_{\mathrm{ik}}-X_{\mathrm{k}}\right)^{2}}{n_{\mathrm{c}}-1} \times 100^{2},
$$

where $\bar{M}=\underline{\sum_{i=1}^{n_{\mathrm{c}}} M_{\mathrm{i}}}$ and represents the average number of winter of csummer flounder collected at site $i$.

\section{Intraspecific dietary analysis}

Hierarchical cluster analyses of \%IRI data were used to examine the diet composition of winter flounder and summer flounder as a function of body size (TL in millimeters). Winter and summer flounder used in the diet study ranged from 20 to $90 \mathrm{~mm}$ TL and from 19 to $172 \mathrm{~mm}$ TL, respectively (preserved lengths). To assess the effect of fish size on diet, before cluster analyses, winter and summer flounder were grouped into 5-mmTL and 10-mm-TL size-class intervals, respectively, and $\% I R I$ was recalculated with Equation 2 (i.e., 1 seine haul produced more than 1 cluster when multiple size classes were present). The statistical software package PRIMER 7.0 (PRIMER-E Ltd., Plymouth, UK) was used to create resemblance matrices of the diet data. For each flounder species, diet data were first logtransformed $(\log [x+1])$ to account for log-normal distributions (Latour et al., 2008), and the Bray-Curtis index was then used to construct a similarity matrix.

Cluster analyses were conducted on the resulting resemblance matrices by using a similarity profiling routine (SIMPROF), which defines statistically distinct groupings among samples (Clarke et al., 2014). Dendrograms derived from cluster analyses were used to visually represent the dietary similarities among size classes of winter and summer flounder (group average method), and similarity percentage analyses (SIMPER) were used to identify the prey taxa that accounted for the dietary similarities or differences within or among groupings. Accordingly, the hierarchical cluster analyses yielded 4 distinct groups of winter and summer flounder (Fig. 3), corresponding to 4 broad size categories. For winter flounder, the size categories were $\leq 39$ mm TL (small), 40-59 mm TL (small-medium), 60-79 $\mathrm{mm}$ TL (medium-large), and $\geq 80 \mathrm{~mm}$ TL (large), and, for summer flounder, the categories were $\leq 59 \mathrm{~mm}$ TL (small), 60-79 mm TL (small-medium), 80-119 $\mathrm{mm}$ TL (medium-large), and $\geq 120 \mathrm{~mm}$ TL (large).

Spatial (site) and temporal (monthly) variations in diet of winter and summer flounder within each riverine system were examined by using 2-way permutational multivariate analysis of variance (PERMANOVA) models, as provided in the PRIMER 7.0 software package (Anderson et al., 2008). Bray-Curtis resemblance matrices of $\log (x+1)$-transformed data were created by using the previously described methods; however, \%IRI was recalculated from Equation 2 by grouping winter and summer flounder into their respective broad size categories (4 size categories for each species; Fig. 3). Therefore, each element in a resemblance matrix represented the mean \%IRI for winter or summer flounder as a function of its size category (small, small-medium, medium-large, and large), site (Seekonk River site 1-4 [SR1-SR4] or Taunton River site 1-4 [TR1-TR4]; Fig. 1), and month (May, June, July, and August- 

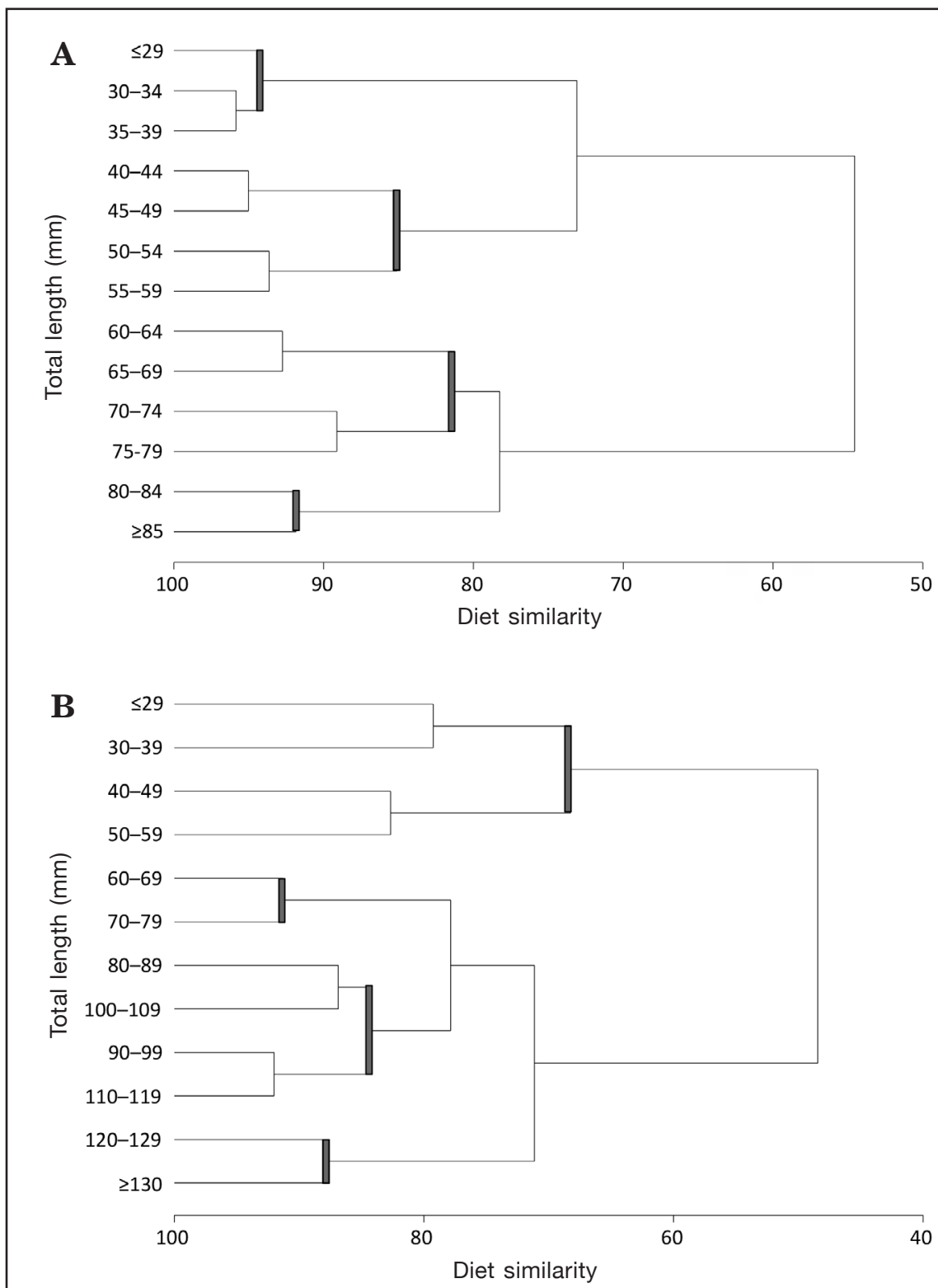

Figure 3

Dendrograms derived from hierarchical cluster analyses and that represent the dietary similarities of (A) winter flounder (Pseudopleuronectes americanus) and (B) summer flounder (Paralichthys dentatus) across 5-mm or 10-mm increments of "preserved" total length (i.e., measured in the laboratory after specimens were preserved in $70 \%$ ethanol). Vertical gray bars represent distinct dietary groups determined from cluster analyses and similarity profiling. Winter and summer flounder were collected from the Seekonk and Taunton Rivers during 2009-2015.

September). Interannual variations in diet (2009-2015) were excluded from these analyses because some sites were not consistently sampled across years (i.e., SR1, SR3, and TR3).

If significant results $(P<0.05)$ were obtained with the PERMANOVA models, SIMPER analyses were conducted to determine which prey taxa contributed to the observed differences in diet of winter and summer flounder across sites or months. Further, to aid in the interpretation of the PERMANOVA results, principal coordinate analysis (PCO) was used to visualize the diet composition data. This method provides a direct projection of data points in space according to their actual dissimilarities, and PCO axes quantify the amount of variation inherent in the resemblance matrix that is attributable to each successive PCO axis (expressed as 
a percentage of total variation) (Anderson et al., 2008). Moreover, by using Pearson correlations, vectors of the dominant prey taxa $(\% I R I>1.8 \%)$ were superimposed onto the PCO biplots, which correspond to the monotonic relationships between the dietary importance of a prey and the PCO axes (Anderson et al., 2008).

Diet diversity for winter and summer flounder was estimated by using the Levins index of niche breadth (B) (Levins, 1968), such that

$$
B=\frac{1}{n_{\mathrm{p}}-1}\left(\frac{1}{\sum_{k=1}^{n_{\mathrm{p}}} P_{\mathrm{k}}^{2}}-1\right),
$$

where $B=$ the standardized index of niche breadth for winter or summer flounder;

$P_{\mathrm{k}}=$ the proportional contribution of prey taxon $k$ to the diet of a flounder species (based on $\left.I R I_{\mathrm{k}}\right)$; and

$n_{\mathrm{p}}=$ the total number of prey taxa identified in the stomachs of a flounder species.

Values of $B$ range between 0 and 1 , and a value of 0 indicates maximum dietary specialization and a value of 1 indicates nondiscrimination of prey. Moreover, $B>0.6$ denotes a high niche breadth, whereas values of $0.4-$ 0.6 and $<0.4$ represent moderate and low diet diversity, respectively (Novakowski et al., 2008). In this study, $B$ was calculated for winter and summer flounder irrespective of their body sizes (the size-independent estimate) and at specific size classes (the size-dependent estimate). For the latter, for each sampling site, $B$ was estimated for winter and summer flounder at 5-mm TL and $10-\mathrm{mm}$ TL size-class intervals, respectively. Nonlinear (exponential) regression models were used to examine the effect of body size of winter and summer flounder on diet diversity.

\section{Interspecific dietary overlap}

The extent of dietary overlap between winter flounder and summer flounder was evaluated by using 2 approaches. First, after the procedures described above, 2-way PERMANOVA models, PCO biplots, and SIMPER analyses were used to examine similarities in diet composition as a function of species type (winter or summer flounder) and size categorization (small, small-medium, medium-large, or large). Second, the Schoener index was used to assess interspecific dietary overlap (Schoener, 1970), such that

$$
\alpha=1-0.5\left(\sum_{k=1}^{n_{\mathrm{p}}} \mid P_{\mathrm{hk}}-P_{\mathrm{jk}}\right),
$$

where $\alpha$ estimates the degree of resource overlap between flounder species; and

$P_{\mathrm{hk}}$ and $P_{\mathrm{jk}}=$ the proportional contributions of prey taxon $k$ (based on $I R I_{\mathrm{k}}$ ) to the diet of winter flounder $(h)$ and summer flounder $(j)$, respectively.

The result is an $\alpha$ value that ranges between 0 and
1 , and $\alpha>0.6$ denotes biologically significant overlap in the use of prey resources (Schoener, 1970), whereas values of $0.4-0.6$ and $<0.4$ represent moderate and low dietary overlap, respectively (Hartman and Brandt, 1995; Novakowski et al., 2008; Zahn Seegert et al., 2014). In this study, the Schoener index was calculated for winter and summer flounder irrespective of their body sizes (size-independent estimate) and for winter and summer flounder of equivalent sizes (size-dependent estimates). For the latter, for each sampling site, $\alpha$ was evaluated for winter and summer flounder at 5-mm-TL increments ranging from 20 to $90 \mathrm{~mm}$ TL (14 total increments). A nonlinear (logarithmic) regression model was used to examine the effect of fish body size on the extent of dietary overlap.

\section{Results}

\section{Intraspecific diet composition and diversity}

During 2009-2015, winter flounder and summer flounder were collected from 186 and 132 seine hauls, respectively, in the Seekonk and Taunton Rivers (Table 2 ). The stomachs of 1109 winter flounder and 749 summer flounder were examined in total, of which $89.8 \%$ and $95.3 \%$ contained prey. In stomachs of winter flounder, 33 unique prey taxa were identified (mean number of prey taxa per stomach: 3.0 [standard error (SE)] 0.04) (Table 2). The dominant prey of winter flounder, with respect to the \%IRI, were amphipods, harpacticoid and calanoid copepods, polychaetes, bivalves (e.g., clam siphons), insects (e.g., chironomid larvae), and isopods (Table 2). Collectively, these taxa accounted for $98.8 \%$ of the relative diet of winter flounder $20-90 \mathrm{~mm}$ TL. Other prey that were of lesser dietary importance, yet relatively common in stomachs of winter flounder $(\% F>1 \%)$, included ostracods, nematodes, and mysid shrimp. Summer flounder 19-172 mm TL consumed 32 different prey taxa and each stomach contained, on average, 2.1 (SE 0.03) prey taxa (Table 2). Five prey taxa composed $98.9 \%$ of the diet of summer flounder (based on \%IRI): mysid shrimp, sand shrimp, amphipods, fish, and copepods (Table 2). Other prey encountered at relatively high frequencies in stomachs of summer flounder $(\% F>1 \%)$ were polychaetes, cumaceans, clam siphons, and ostracods.

According to the niche breadth index, a low level of diet diversity was observed for both winter and summer flounder when calculations were made irrespective of body size ( $B$ : 0.24 and 0.30 ; Table 2). Niche dietary breadth of winter and summer flounder, however, significantly expanded with increasing body lengths (exponential regression: winter flounder, $F=11.05$, coefficient of determination $\left[r^{2}\right]=0.104, P<0.005$; summer flounder, $F=6.61, r^{2}=0.09, P<0.05$ ) (Fig. 4, A and B). Specifically, winter flounder had a moderate and high degree of diet diversity when individuals exceeded $\sim 75 \mathrm{~mm}$ TL $(B \geq 0.4)$, and this broader-based diet was most evident in the Taunton River (Fig. 4A). For summer flounder, 
Table 2

Contributions of prey taxa to the diets of winter flounder (Pseudopleuronectes americanus) and summer flounder (Paralichthys dentatus) expressed as frequency of occurrence $(\% F)$, numeric percentage $(\% N)$, volumetric percentage $(\% V)$, and the index of relative importance (\%IRI, Eq. 1). Mean values (and standard errors [SEs]) were calculated by using a cluster sampling estimator (Eqs. 2 and 3). Size-independent estimates of Levins niche breadth index (B; Eq. 4) and Schoener dietary overlap index ( $\alpha$; Eq. 5) are also presented. Winter and summer flounder were collected from the Seekonk and Taunton Rivers during $2009-2015$.

\begin{tabular}{|c|c|c|c|c|c|c|c|c|}
\hline \multirow[b]{2}{*}{ Prey taxon } & \multicolumn{4}{|c|}{ Winter flounder } & \multicolumn{4}{|c|}{ Summer flounder } \\
\hline & $\% F$ & $\% N$ & $\% V$ & $\% I R I$ & $\% F$ & $\% N$ & $\% V$ & $\% I R I$ \\
\hline \multicolumn{9}{|l|}{ Crustaceans } \\
\hline $\begin{array}{l}\text { Amphipoda (amphipod) } \\
\text { Isopoda (isopod) }\end{array}$ & $81.2(\mathrm{SE} 0.3)$ & 27.9 (SE 0.3) & 47.7 (SE 0.3) & 48.3 (SE 0.3) & $41.9(\mathrm{SE} 0.4)$ & 14.8 (SE 0.3) & 15.6 (SE 0.2) & $15.0(\mathrm{SE} 0.3)$ \\
\hline Anthuridae (anthurid isopod) & 8.4 (SE 0.3) & $1.3(\mathrm{SE} 0.1)$ & 2.3 (SE 0.1$)$ & $1.3(\mathrm{SE} 0.1)$ & - & - & - & - \\
\hline Idoteidae (idoteid isopod) & 3.4 (SE 0.1) & $0.4(\mathrm{SE} 0.01)$ & 0.7 (SE 0.03) & $0.4(\mathrm{SE} 0.02)$ & $0.2(\mathrm{SE} 0.02)$ & $<0.1$ & $0.2(\mathrm{SE} 0.01)$ & $<0.1$ \\
\hline Tanaidacea (tanaid) & - & - & - & - & $0.3(\mathrm{SE}$ 0.02) & $<0.1$ & $<0.1$ & $<0.1$ \\
\hline Cumacea (cumacean) & 0.3 (SE 0.08) & $<0.1$ & $<0.1$ & $<0.1$ & 1.8 (SE 0.1) & 0.3 (SE 0.01$)$ & 0.4 (SE 0.02) & $0.2(\mathrm{SE} 0.02)$ \\
\hline $\begin{array}{l}\text { Calanoida/Harpacticoida } \\
\text { (copepod) }\end{array}$ & 66.4 (SE 0.4) & 44.5 (SE 0.4) & $19.4(\mathrm{SE} 0.2)$ & 25.6 (SE 0.3) & 14.5 (SE 0.3) & 15.5 (SE 0.5) & 3.7 (SE 0.1) & $4.0(\mathrm{SE} 0.1)$ \\
\hline Ostracoda (ostracod) & 8.9 (SE 0.2) & 0.6 (SE 0.01) & 0.4 (SE 0.01) & 0.1 (SE 0.01) & 1.1 (SE 0.1) & 0.2 (SE 0.01$)$ & $<0.1$ & $<0.1$ \\
\hline $\begin{array}{l}\text { Mysidacea } \\
\text { (mysid shrimp) }\end{array}$ & $1.3(\mathrm{SE} 0.1)$ & $<0.1$ & 0.2 (SE 0.01$)$ & 0.1 (SE 0.01) & 70.8 (SE 0.5) & $51.6(\mathrm{SE} 0.5)$ & 49.1 (SE 0.6) & 54.4 (SE 0.6) \\
\hline Decapoda (decapod) & & & & & & & & \\
\hline $\begin{array}{l}\text { Crangon septemspinosa } \\
\text { (sand shrimp) }\end{array}$ & $<0.1$ & $<0.1$ & $<0.1$ & $<0.1$ & 29.6 (SE 0.5) & $10.4(\mathrm{SE} 0.2)$ & 20.1 (SE 0.4) & $18.6($ SE 0.4$)$ \\
\hline Palaemonidae (grass shrimp) & - & - & - & - & 0.1 (SE 0.01) & $<0.1$ & 0.1 (SE 0.01) & $<0.1$ \\
\hline Callinectes sapidus (blue crab) & - & - & - & - & $0.2(\mathrm{SE} 0.01)$ & $<0.1$ & $<0.1$ & $<0.1$ \\
\hline $\begin{array}{l}\text { Grapsidae or Xanthidae } \\
\text { (shore or mud crab) }\end{array}$ & 0.8 (SE 0.03) & $0.3($ SE 0.01$)$ & 0.4 (SE 0.01) & $0.3($ SE 0.01$)$ & 0.8 (SE 0.03) & 0.2 (SE 0.01$)$ & 0.4 (SE 0.01) & $0.2(\mathrm{SE} 0.01)$ \\
\hline $\begin{array}{l}\text { Pagurus longicarpus } \\
\text { (longwrist hermit) }\end{array}$ & $<0.1$ & $<0.1$ & $<0.1$ & $<0.1$ & 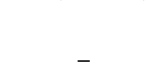 & 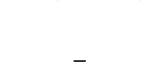 & 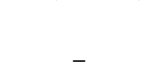 & - \\
\hline $\begin{array}{r}\text { Unidentified crab } \\
\text { (zoea life stage) }\end{array}$ & $<0.1$ & $<0.1$ & $<0.1$ & $<0.1$ & - & - & - & - \\
\hline $\begin{array}{l}\text { Unidentified crab } \\
\text { (megalope life stage) }\end{array}$ & 0.9 (SE 0.03) & 0.3 (SE 0.01) & 0.2 (SE 0.01) & $0.2($ SE 0.01$)$ & $0.2(\mathrm{SE} 0.01)$ & $<0.1$ & $<0.1$ & $<0.1$ \\
\hline Unidentified crustacean & 0.3 (SE 0.02) & $<0.1$ & $<0.1$ & $<0.1$ & $0.2(\mathrm{SE} 0.01)$ & 0.1 (SE 0.01) & $<0.1$ & $<0.1$ \\
\hline Insects & & & & & & & & \\
\hline Chironomidae (midge larvae) & 22.8 (SE 0.5) & 6.9 (SE 0.2) & 8.9 (SE 0.2) & $6.3(\mathrm{SE} 0.2)$ & $0.2(\mathrm{SE} 0.01)$ & $<0.1$ & $<0.1$ & $<0.1$ \\
\hline Coleoptera (beetle) & $<0.1$ & $<0.1$ & $<0.1$ & $<0.1$ & - & - & - & - \\
\hline Diptera (pupae life stage) & $<0.1$ & $<0.1$ & $<0.1$ & $<0.1$ & 0.4 (SE 0.03) & $<0.1$ & 0.1 (SE 0.01) & $<0.1$ \\
\hline Formicidae (ant) & $<0.1$ & $<0.1$ & $<0.1$ & $<0.1$ & - & - & - & - \\
\hline Unidentified insect & $<0.1$ & $<0.1$ & $<0.1$ & $<0.1$ & 0.7 (SE 0.05) & 0.1 (SE 0.01) & $<0.1$ & $<0.1$ \\
\hline Arachnids & & & & & & & & \\
\hline Acarina (mite) & $<0.1$ & $<0.1$ & $<0.1$ & $<0.1$ & - & - & - & - \\
\hline Aranae (spider) & - & - & - & - & 0.1 (SE 0.01) & $<0.1$ & $<0.1$ & $<0.1$ \\
\hline
\end{tabular}

niche dietary breadth was more variable across lengths and riverine sites, and moderate and high diet diversity was common for summer flounder $>115 \mathrm{~mm}$ TL (Fig. 4B).

\section{Ontogenetic effects on intraspecific diets}

Hierarchical cluster analyses revealed distinct dietary groups for winter flounder and summer flounder, and these groups corresponded with 4 broad size categories for each species (Fig. 3). After accounting for the sizedependent effects on diet, the corrected cluster sample sizes for winter and summer flounder $\left(n_{\mathrm{c}}\right)$ equaled 242 and 157, respectively (i.e., 1 seine haul resulted in $>1$ cluster when multiple size classes were present). Small winter flounder ( $\leq 39 \mathrm{~mm}$ TL) had a $94.9 \%$ similarity in diet (SIMPROF: $\pi=0.16, P=0.83$; Fig. $3 \mathrm{~A}$ ) and fed predominantly on copepods $(\% I R I=76.5 \%)$, polychaetes (\%IRI $=11.8 \%$; unidentified and Fabricia sabella), and amphipods (\%IRI=11.4\%) (Fig. 5A). Winter flounder 
Table 2 (Continued)

\begin{tabular}{|c|c|c|c|c|c|c|c|c|}
\hline \multirow[b]{2}{*}{ Prey taxon } & \multicolumn{4}{|c|}{ Winter flounder } & \multicolumn{4}{|c|}{ Summer flounder } \\
\hline & $\% F$ & $\% N$ & $\% V$ & $\% I R I$ & $\% F$ & $\% N$ & $\% V$ & $\% I R I$ \\
\hline \multicolumn{9}{|l|}{ Worms } \\
\hline \multicolumn{9}{|l|}{ Polychaeta (polychaete) } \\
\hline \multicolumn{9}{|l|}{ Ampharetidae } \\
\hline (ampharetid worm) & 1.9 (SE 0.04) & 0.3 (SE 0.01) & $0.6(\mathrm{SE} 0.01)$ & 0.2 (SE 0.01) & 0.1 (SE 0.01) & $<0.1$ & $<0.1$ & $<0.1$ \\
\hline Fabricia sabella (fan worm) & $8.6(\mathrm{SE} 0.2)$ & $2.8(\mathrm{SE} 0.1)$ & $1.9(\mathrm{SE} 0.1)$ & $1.6(\mathrm{SE} 0.1)$ & 0.2 (SE 0.04) & $<0.1$ & $<0.1$ & $<0.1$ \\
\hline Glyceridae (blood worm) & 0.1 (SE 0.01) & $<0.1$ & $<0.1$ & $<0.1$ & - & - & - & - \\
\hline Nereididae (clam worm) & $2.1(\mathrm{SE} 0.1)$ & $0.3($ SE 0.01$)$ & $0.6($ SE 0.02$)$ & $0.2(\mathrm{SE} 0.01)$ & 0.5 (SE 0.03) & $<0.1$ & $<0.1$ & $<0.1$ \\
\hline Phyllodocidae (paddle worm) & $8.0(\mathrm{SE} 0.2)$ & 0.9 (SE 0.02) & $1.2(\mathrm{SE} 0.03)$ & 0.6 (SE 0.01) & - & - & - & - \\
\hline Polydora spp. (mud worm) & $4.3(\mathrm{SE} 0.1)$ & 1.4 (SE 0.04) & $1.1(\mathrm{SE} 0.03)$ & 0.8 (SE 0.03) & - & - & - & - \\
\hline Unidentified polychaete & 26.6 (SE 0.4) & $4.8(\mathrm{SE} 0.1)$ & 8.1 (SE 0.1) & $5.8(\mathrm{SE} 0.1)$ & 3.9 (SE 0.1) & 0.7 (SE 0.02) & $1.0(\mathrm{SE} 0.03)$ & 0.4 (SE 0.02) \\
\hline Nematoda (nematode) & $2.1(\mathrm{SE} 0.1)$ & $0.2($ SE 0.01$)$ & $<0.1$ & $<0.1$ & 0.1 (SE 0.01) & $<0.1$ & $<0.1$ & $<0.1$ \\
\hline \multicolumn{9}{|l|}{ Mollusks } \\
\hline \multicolumn{9}{|l|}{ Bivalvia (bivalve) } \\
\hline Mya arenaria (softshell) & 0.1 (SE 0.01) & $<0.1$ & $<0.1$ & $<0.1$ & - & - & - & - \\
\hline \multicolumn{9}{|l|}{ Unidentified clam } \\
\hline \multicolumn{9}{|l|}{ Unidentified clam } \\
\hline Gastropoda & 0.2 (SE 0.01) & $<0.1$ & $<0.1$ & $<0.1$ & - & - & - & - \\
\hline \multicolumn{9}{|l|}{ Fish } \\
\hline \multicolumn{9}{|l|}{ Anguilla rostrata } \\
\hline (American eel) & - & - & - & - & 0.1 (SE 0.01) & $<0.1$ & $<0.1$ & $<0.1$ \\
\hline \multicolumn{9}{|l|}{ Catostomus commersoni } \\
\hline Clupeidae (herring) & - & - & - & - & 1.0 (SE 0.04) & 0.3 (SE 0.01$)$ & 0.7 (SE 0.03) & 0.4 (SE 0.02) \\
\hline Gobiidae (goby) & - & - & - & - & 0.1 (SE 0.01) & $<0.1$ & $<0.1$ & $<0.1$ \\
\hline \multicolumn{9}{|l|}{ Menidia menidia } \\
\hline (Atlantic silverside) & - & - & - & - & 0.1 (SE 0.01) & 0.1 (SE 0.01) & 0.1 (SE 0.01) & 0.1 (SE 0.01) \\
\hline \multicolumn{9}{|l|}{ Micropterus salmoides } \\
\hline (largemouth bass) & - & - & - & - & 0.1 (SE 0.01) & $<0.1$ & $<0.1$ & $<0.1$ \\
\hline \multicolumn{9}{|l|}{ Pseudopleuronectes americanus } \\
\hline (winter flounder) & - & - & - & - & 2.4 (SE 0.1) & 0.3 (SE 0.01) & 1.1 (SE 0.04) & 0.4 (SE 0.02) \\
\hline \multicolumn{9}{|l|}{ Syngnathus fuscus } \\
\hline (northern pipefish) & - & - & - & - & 0.3 (SE 0.01) & $<0.1$ & $<0.1$ & $<0.1$ \\
\hline Unidentified fish & - & - & - & - & 8.8 (SE 0.3) & 4.7 (SE 0.3) & $6.2(\mathrm{SE} 0.3)$ & $5.2(\mathrm{SE} 0.3)$ \\
\hline Detritus & $0.4(\mathrm{SE} 0.02)$ & $<0.1$ & $0.3(\mathrm{SE} 0.02)$ & $0.2(\mathrm{SE} 0.01)$ & 0.6 (SE 0.02) & $<0.1$ & $0.2(\mathrm{SE} 0.01)$ & $<0.1$ \\
\hline \multicolumn{9}{|l|}{ Total number of stomachs } \\
\hline \multicolumn{2}{|l|}{$\begin{array}{l}\text { examined }\left(n_{\mathrm{t}}\right) \\
\text { Percentage of empty stomachs }(\%)\end{array}$} & 10 & .2 & & & 4.7 & & \\
\hline \multicolumn{9}{|l|}{ Total number of clusters (seine hauls } \\
\hline \multicolumn{2}{|c|}{ with winter or summer flounder; $n_{\mathrm{c}}$ ) } & \multicolumn{2}{|c|}{186} & & & 132 & & \\
\hline Unique prey per stomach (mean) & & $3.0(\mathrm{SH}$ & E.04) & & & 2.1 (SE 0.0 & & \\
\hline Niche breadth index $(B)$ & & 0. & 24 & & & 0.30 & & \\
\hline Dietary overlap index $(\alpha)$ & & & & 0.20 & & & & \\
\hline
\end{tabular}

within the small-medium (40-59 $\mathrm{mm}$ TL) and medium-large (60-79 mm TL) size categories had $85.1 \%$ and $81.4 \%$ dietary similarities, respectively (SIMPROF: small-medium, $\pi=2.42, P=0.10$; medium-large, $\pi=2.21$, $P=0.20$; Fig. 3A). Consumption of polychaetes remained consistent at these moderate body sizes (\%IRI 1013\%; unidentified, $F$. sabella, and Polydora spp.), but there was a decreased reliance on copepods (\%IRI declined from $48.9 \%$ to $5.1 \%$ ) and a greater importance of amphipods (\%IRI increased from $34.3 \%$ to $63.7 \%$ )
(Fig. 5A). There also was evidence of small-medium and medium-large winter flounder feeding on bivalves, and that feeding was mostly limited to siphon cropping (\%IRI: $5.9 \%$ and $13.7 \%$ for small-medium and medium-large size categories, respectively) (Table 2). Large winter flounder ( $\geq 80 \mathrm{~mm}$ TL) had $91.8 \%$ dietary similarity (SIMPROF: $\pi=0.00, P=1.00$; Fig. 3A). There was an absence of copepods in the diet of these winter flounder ( $\% I R I=0.0 \%)$, and amphipods (\%IRI=51.7\%), polychaetes $(\% I R I=22.4 \%$; unidentified and nereidids), 

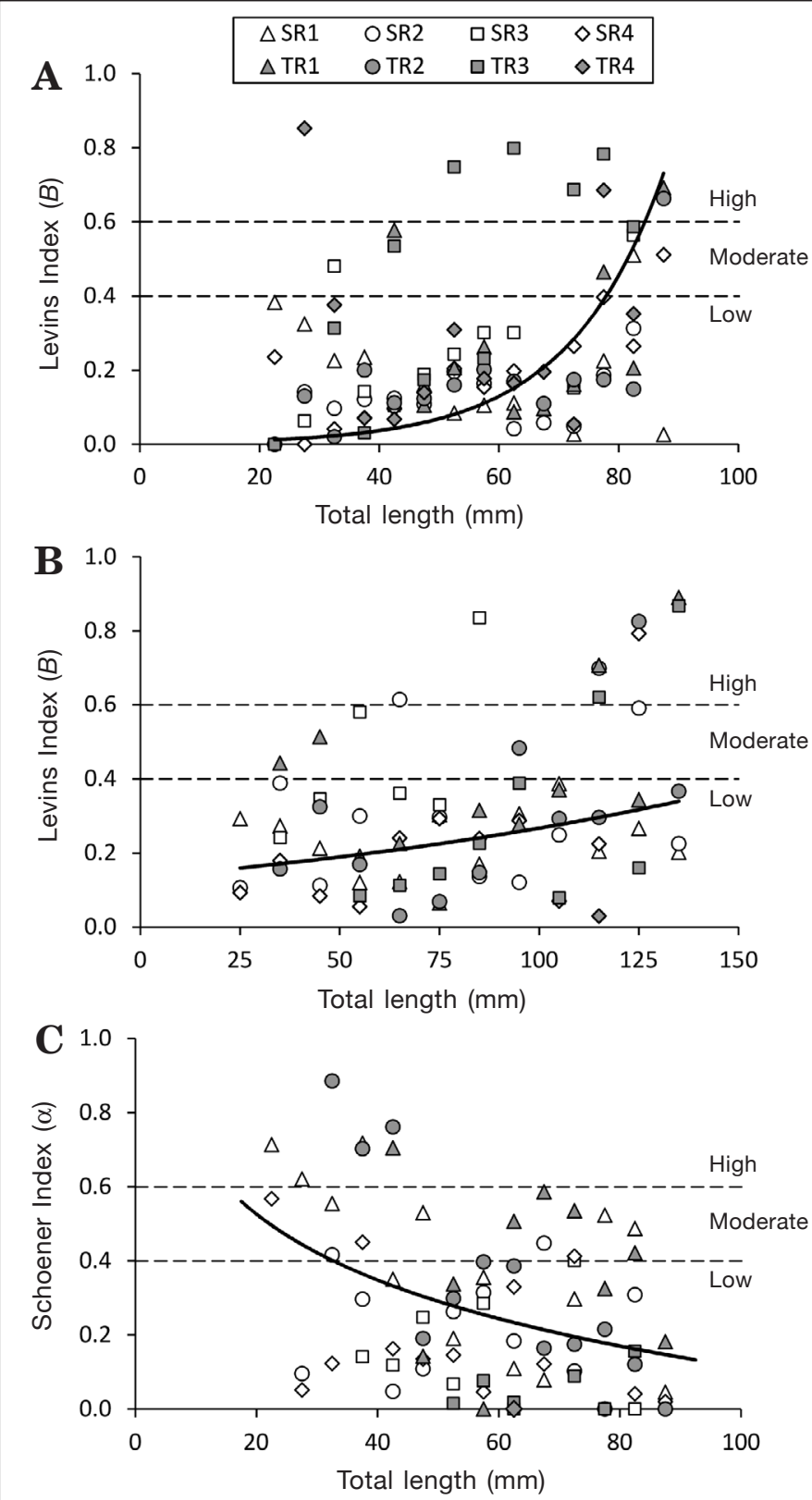

Figure 4

Diet diversity and dietary overlap of winter flounder (Pseudopleuronectes americanus) and summer flounder (Paralichthys dentatus) as a function of "preserved" total length (i.e., measured in the laboratory after specimens were preserved in $70 \%$ ethanol) and riverine site (for locations of sampling sites, see Fig. 1). Diet diversity of (A) winter flounder and (B) summer flounder was expressed by the Levins index of niche breadth (B; Eq. 4), and horizontal dashed lines differentiate among high $(B>0.6)$, moderate $(B=0.4-0.6)$, and low $(B<0.4)$ niche breadths. (C) Dietary overlap is expressed by the Schoener index ( $\alpha$; Eq. 5), and horizontal dashed lines differentiate high $(\alpha>0.6)$, moderate $(\alpha=0.4-0.6)$, and low $(\alpha<0.4)$ overlap. Nonlinear (exponential or logarithmic) regression models were fitted to the data and are represented by the solid lines. Winter and summer flounder were collected from the Seekonk River (SR) and Taunton River (TR) during 2009-2015. and bivalves (\%IRI $=18.4 \%)$ remained important food items (Fig. 5A). The largest winter flounder also consumed isopods and crabs (e.g., megalope) in relatively high proportions (\%IRI: $3.1 \%$ and $4.0 \%$, respectively) (Table 2 , Fig. $5 \mathrm{~A}$ ).

Summer flounder within the smallest size category ( $\leq 59 \mathrm{~mm} \mathrm{TL})$ had $68.2 \%$ dietary similarity (SIMPROF: $\pi=1.88, P=0.69$; Fig. $3 \mathrm{~B}$ ), with mysid shrimp, copepods, and amphipods representing the most dominant prey (\%IRI: $59.5 \%, 22.9 \%$, and $15.1 \%$, respectively), and sand shrimp and fish consigned to secondary importance $(\% I R I \leq 1.3 \%)$ (Fig. 5B). The similarities in diet of summer flounder within the other size classes ranged between $84.2 \%$ and $91.3 \%$ (SIMPROF: small-medium [60-79 mm TL], $\pi=0.00, P=1.00$; medium-large [80-119 $\mathrm{mm}$ TL], $\pi=1.25, P=0.63$; large $[\geq 120$ $\mathrm{mm}$ TL], $\pi=0.00, P=1.00$; Fig. 3B). Copepods were not observed in the stomachs of moderate- and large-size summer flounder (\%IRI=0.0\%; Fig. 5B). Moreover, progressive increases in size of summer flounder resulted in a decline in the dietary importance of mysid shrimp and amphipods (\%IRI: mysid shrimp, from $35.6 \%$ to $6.4 \%$; amphipods, from $43.7 \%$ to $17.5 \%$ ), whereas sand shrimp and fish became increasingly more dominant (\%IRI: shrimp, from $19.2 \%$ to $66.8 \%$; fish, from $1.0 \%$ to $6.0 \%$ ) (Fig. 5B). Of the identifiable fish remains in the stomachs of summer flounder, winter flounder had the highest $\% F(2.4 \%)$ and $\% I R I(0.4 \%)$ (Table 2), verifying predator-prey interactions between the focal species.

\section{Spatiotemporal effects on intraspecific diets}

Winter flounder diet in the Seekonk and Taunton Rivers varied statistically by site and month (2-way PERMANOVA: site, pseudo$F=3.04-4.77, \quad P<0.01-0.001$; month, pseudo$F=4.94-10.07, P<0.001$ ), and the site-month interaction effects were not significant (2-way PERMANOVA: site $\times$ month, pseudo- $F=0.73-1.77$, $P=0.06-0.75$ ) (Fig. 6). Principal coordinate analysis revealed that month most closely corresponded with the first PCO axis (PCO1) and accounted for $56.7 \%$ and $59.3 \%$ of the explainable variation in diet of winter flounder in the Seekonk and Taunton Rivers (Fig. 6, B and D). The second $\mathrm{PCO}$ axis (PCO2), in contrast, was best represented by riverine sites (SR1-SR4 or TR1-TR4) and accounted for $20.5-28.8 \%$ of the total variation in diet. Differences in diet of winter flounder across months were attributed mainly to the importance of copepods at the onset of this study (from May through August-September, \%IRI for copepods declined from $61.6 \%$ to $0.8 \%$ ), and copepods were steadily replaced by polychaetes thereafter (from May through August-September, \%IRI for polychaetes increased from $5.1 \%$ to 42.6\%) (Fig. 6, A and C). 
Moreover, in the Taunton River, winter flounder consumed a high proportion of crab megalope in July and August-September, especially in the middle and upper portions of the river (TR1-TR3, July and August-September \%IRI for crab: 1.6-39.4\%). Spatial differences in the diet of winter flounder from the Taunton River were attributed also to the disproportionate contribution of bivalves and anthurid isopods in the upper reaches of the river (TR1 and TR2 \%IRI: bivalve=7.4-26.4\%; isopod=3.0 $-12.4 \%$ ), and polychaetes were dominant at TR4, particularly from midto late summer (TR4, July and AugustSeptember \%IRI for polychaetes, mostly unidentified, phyllodocid, and Polydora spp., was 52.0-77.4\%) (Fig. 6C). In contrast, bivalves and idoteid isopods were important prey in the lower reaches of the Seekonk River (SR3 and SR4 \%IRI: bivalves $=9.1-27.6 \%$; isopod $=2.3-6.3 \%$ ), whereas chironomid larvae were relatively unique to SR2 (SR2 \%IRI for chironomids: 1.2-20.0\%) (Fig. 6A). Amphipods were a broadly used prey resource by winter flounder, but no discernible spatiotemporal patterns in their dietary contribution were evident (Fig. 6).

Summer flounder feeding habits in each river varied temporally (2-way PERMANOVA for month: Seekonk, pseudo$F=5.39, P<0.001$; Taunton, pseudo $-F=3.86$, $P<0.002$ ), but dietary differences across sites were evident only in the Taunton River (2-way PERMANOVA for site: Seekonk, pseudo- $F=1.90, P=0.08$; Taunton, pseudo$F=3.97, P<0.002$ ) (Fig. 7). Further, in each instance, the site-month interaction effect was not significant (2-way PERMANOVA: site $\times$ month, pseudo- $F=0.50-0.64, P=0.79$ 0.96). The first and second axes of the PCO biplots were correlated most with month and site, respectively, and accounted for $55.4-66.5 \%$ and $14.7-24.3 \%$ of the total variation in diet of summer flounder in the Seekonk and Taunton Rivers (Fig. 7, B and D).

The significant temporal variation in diet of summer flounder was attributed to the initial contribution of mysid shrimp and copepods in May-June and subsequent dietary shifts toward amphipods in later months (from May to August-September, \%IRI decreased for mysid shrimp from $54.8 \%$ to $16.2 \%$ and for copepods from $10.9 \%$ to $0.0 \%$ and increased for amphipods from $15.6 \%$ to $50.0 \%$ ) (Fig. 7). The dietary contributions of other important prey taxa, including sand shrimp and fish, varied inconsistently across months. Further, summer flounder collected from the
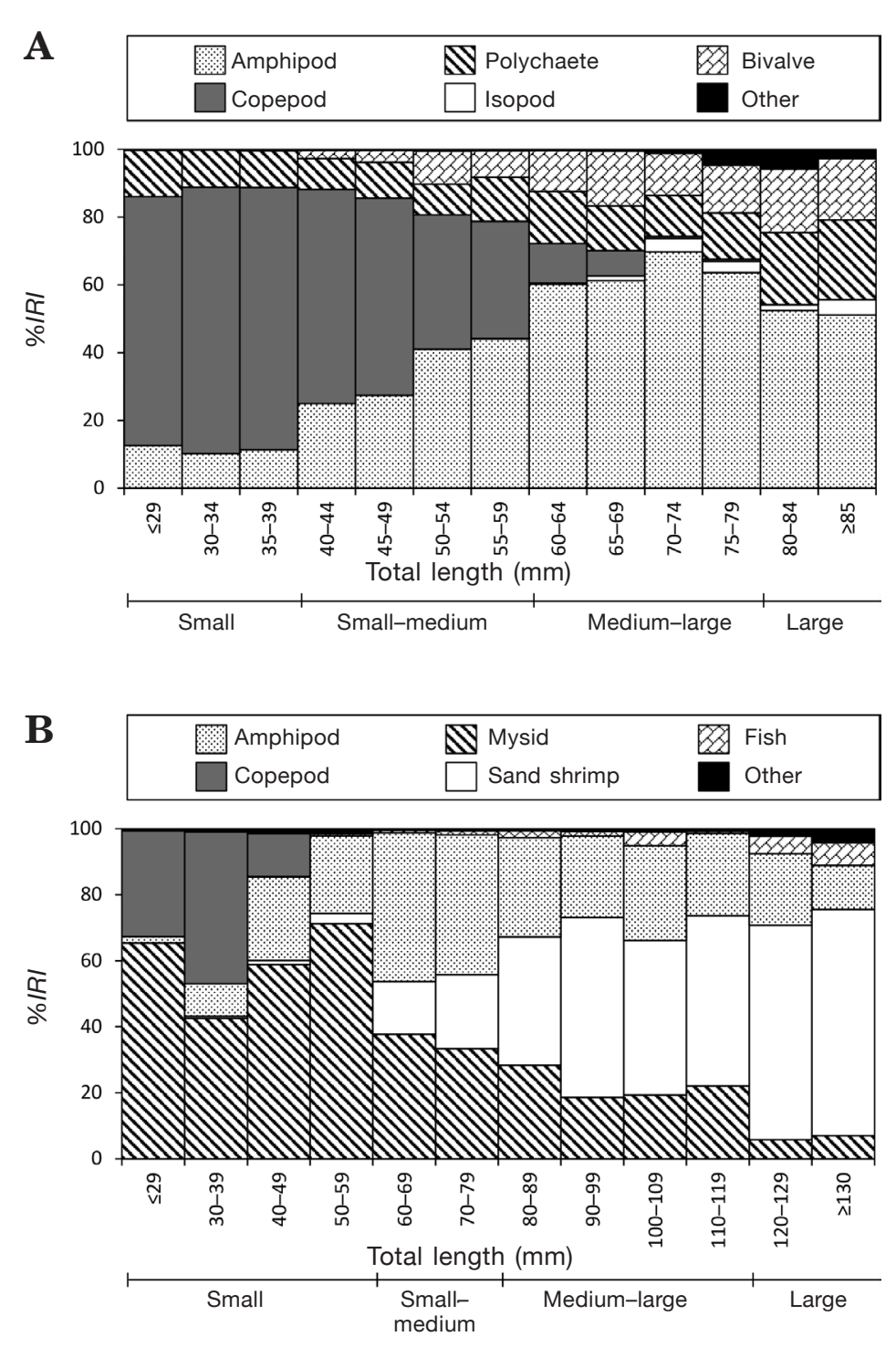

Figure 5

Contributions of prey taxa to the diets of (A) winter flounder (Pseudopleuronectes americanus) and (B) summer flounder (Paralichthys dentatus) as a function of "preserved" total length (i.e., measured in the laboratory after specimens were preserved in $70 \%$ ethanol). Diet is expressed as an index of relative importance (\%IRI; Eq. 1), and horizontal brackets represent distinct (size-based) dietary groups determined from hierarchical cluster analyses and similarity profiling (Fig. 3). Winter and summer flounder were collected from the Seekonk and Taunton Rivers during 2009-2015. 

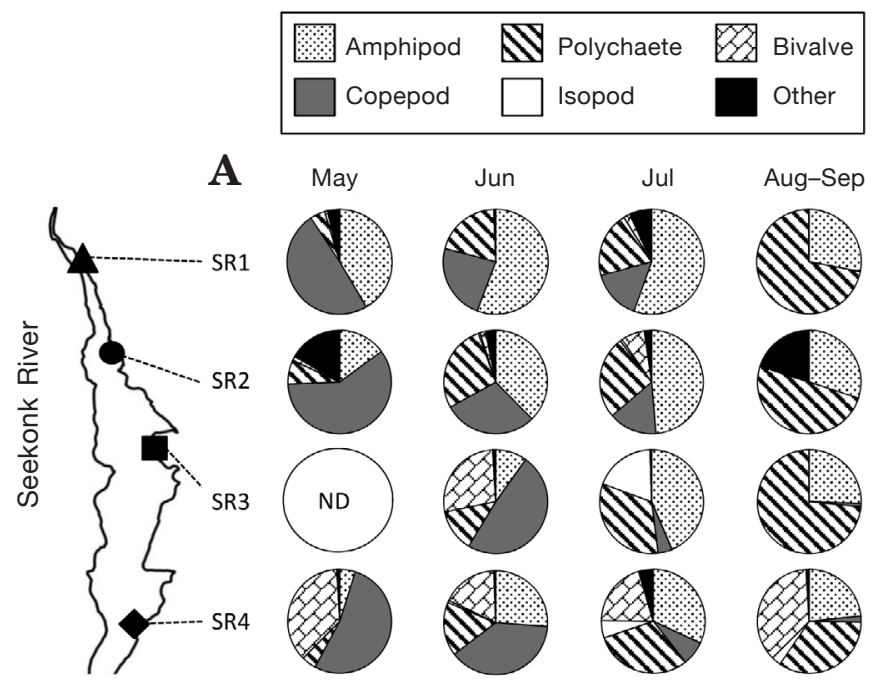

Aug-Sep
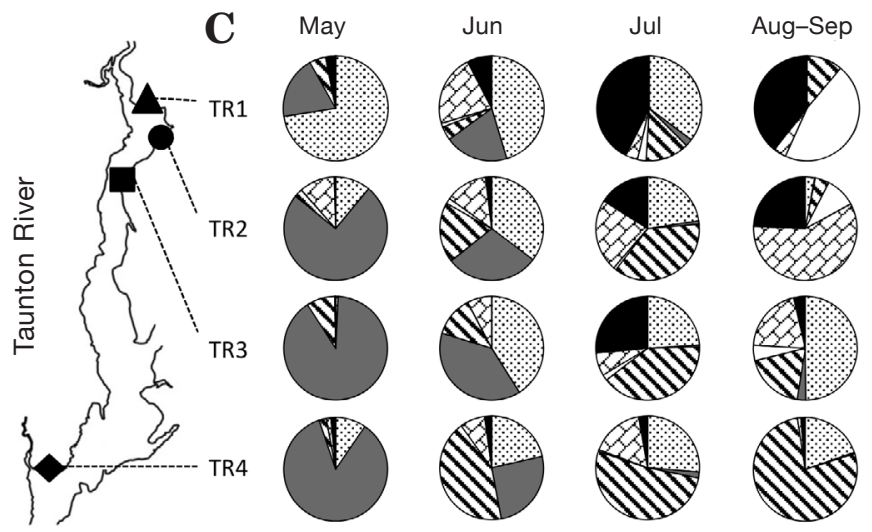

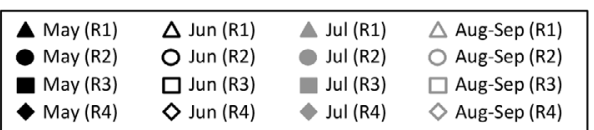

B
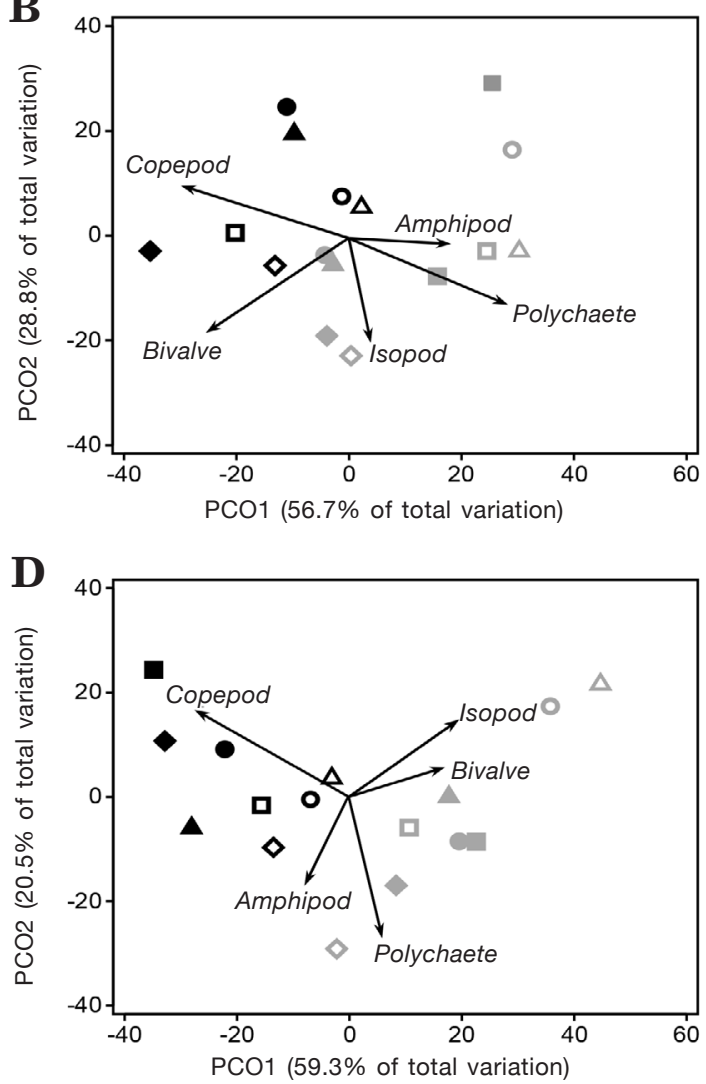

Figure 6

Contributions of prey taxa to the diet of winter flounder (Pseudopleuronectes americanus) collected during 2009-2015 in the (A, B) Seekonk River and (C, D) Taunton River, as a function of month (May-September) and site (SR1-SR4; TR1-TR4). (A, C) Dietary contributions of prey are expressed as an index of relative importance, and (B, D) data points from principal coordinate analysis (PCO) are projected in space according to their actual dissimilarities. Arrows superimposed on the PCO biplots represent vectors of dominant prey taxa, and vectors correspond with the monotonic relationships between the dietary importance of a prey and the PCO axes. The first (PCO1) and second (PCO2) axes correspond with month and site, respectively, and quantify the percentage of total variation in diet of winter flounder. ND signifies no data.

\section{Interspecific dietary overlap}

The diet of winter flounder and summer flounder varied as a function of species type and length classification (2-way PERMANOVA: species, pseudo- $F=77.80$, $P<0.001$; size, pseudo- $F=5.66, P<0.001)$. The speciessize interaction effect also was significant, thereby precluding contrasts across the main effects (2-way PERMANOVA: species $\times$ size, pseudo- $F=3.02, P<0.001$ ). With respect to interspecific comparisons, SIMPER analyses revealed that dietary similarities were highest among small-size winter and summer flounder (average similarity: $29.4 \%$ ), and increasing lengths resulted in greater deviations in their respective diets (average simi- larity among moderate and large winter and summer flounder: 20.3-22.3\%). The higher degree of resource overlap among small winter and summer flounder was attributed to their initial feeding on copepods, followed by ontogenetic dietary shifts away from this shared prey item (Figs. 5-7).

Similarities and differences in the diets of winter and summer flounder were re-affirmed by PCO (Fig. 8). Species type most closely corresponded with the PCO1 and accounted for $40.6 \%$ of the explainable variation in diet. Conversely, body size of winter and summer flounder explained $14.4 \%$ of the total variation in diet and was visually represented by the PCO2. Vectors of the dominant prey taxa were superimposed onto the 


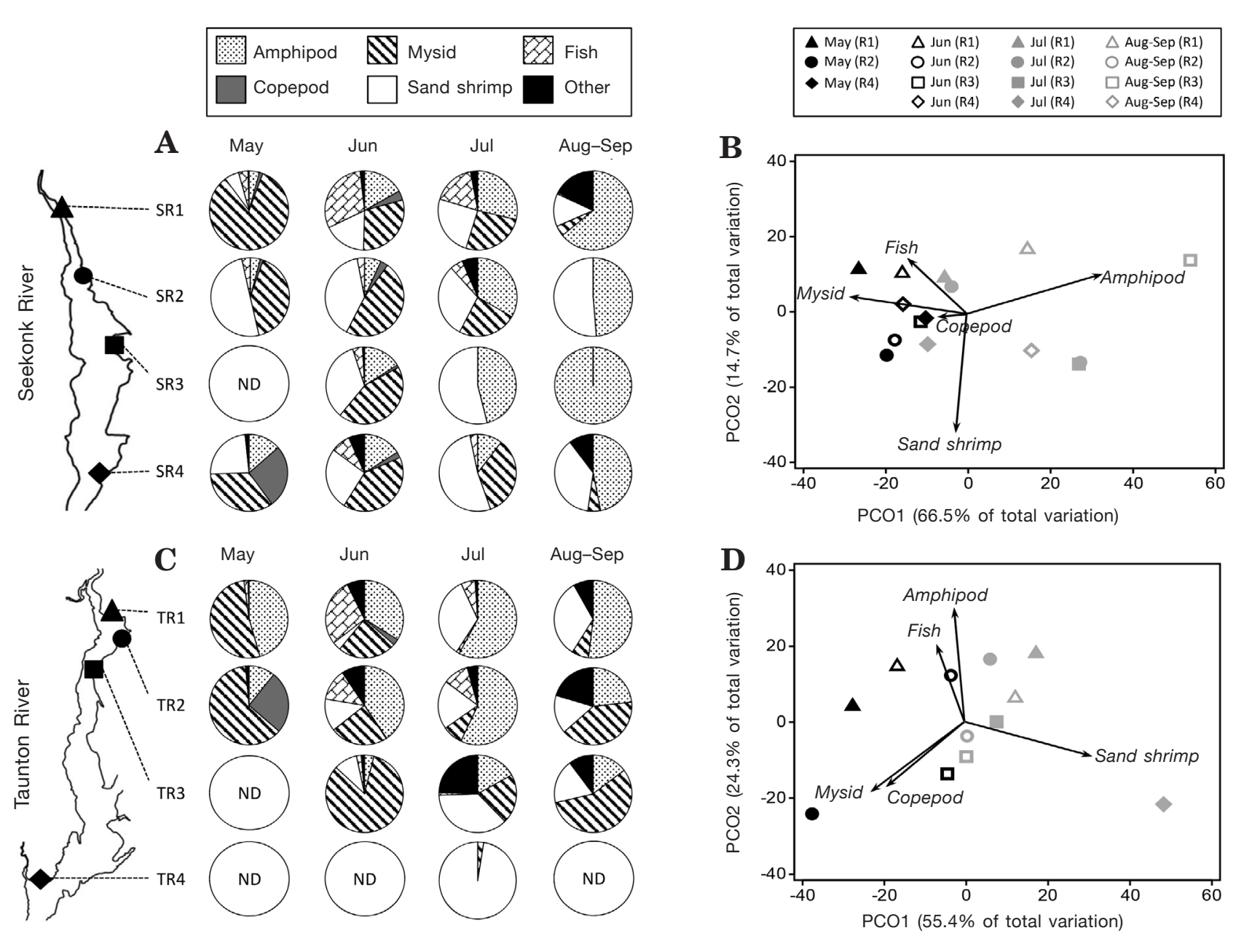

Figure 7

Contributions of prey taxa to the diet of summer flounder (Paralichthys dentatus) collected during 2009-2015 in the (A, B) Seekonk River and (C, D) Taunton River, as a function of month (May-September) and site (SR1-SR4; TR1-TR4). (A, C) Dietary contributions of prey are expressed as the index of relative importance, and (B, D) data points from principal coordinate analysis (PCO) are projected in space according to their actual dissimilarities. Arrows superimposed on the PCO biplots represent vectors of dominant prey taxa, and vectors correspond with the monotonic relationships between the dietary importance of a prey and the PCO axes. The first (PCO1) and second (PCO2) ordination axes correspond with month and site, respectively, and quantify the percentage of total variation in diet of summer flounder. ND signifies no data.

PCO biplots and again verified that copepods and, to a lesser extent, amphipods were shared prey among small and small-medium winter and summer flounder (Fig. 8). Prey vectors also illustrated the positive correlations between winter and summer flounder TL and the discrepancies in their respective diets. For example, although amphipods remained an important prey for both species, moderate- and large-size winter flounder also fed on polychaetes, bivalves, and isopods, whereas sand shrimp and fish became increasingly important to the diet of summer flounder (Fig. 8).

The Schoener index indicated minimal dietary overlap for winter and summer flounder when calculations were made independent of body size ( $\alpha=0.20$; Table 2$)$.
For winter and summer flounder of equivalent sizes, however, dietary overlap was inversely related to total length (logarithmic regression: $F=13.90, r^{2}=0.156$, $P<0.0005$ ) (Fig. 4C). Moderate to high dietary overlap occurred among winter and summer flounder at sizes $<40 \mathrm{~mm}$ TL $(\alpha \geq 0.4)$, and that overlap was due to their mutual reliance on copepods, as described previously (Figs. 5-7). There was also evidence of resource sharing among winter and summer flounder as large as $85 \mathrm{~mm}$ TL (Fig. 4C), and that resource sharing was attributed to both species continually feeding on amphipods (Figs. 5-7). There was a spatial component to dietary overlap, as well, such that similarities in the diet composition of winter and summer flounder were most prevalent in 


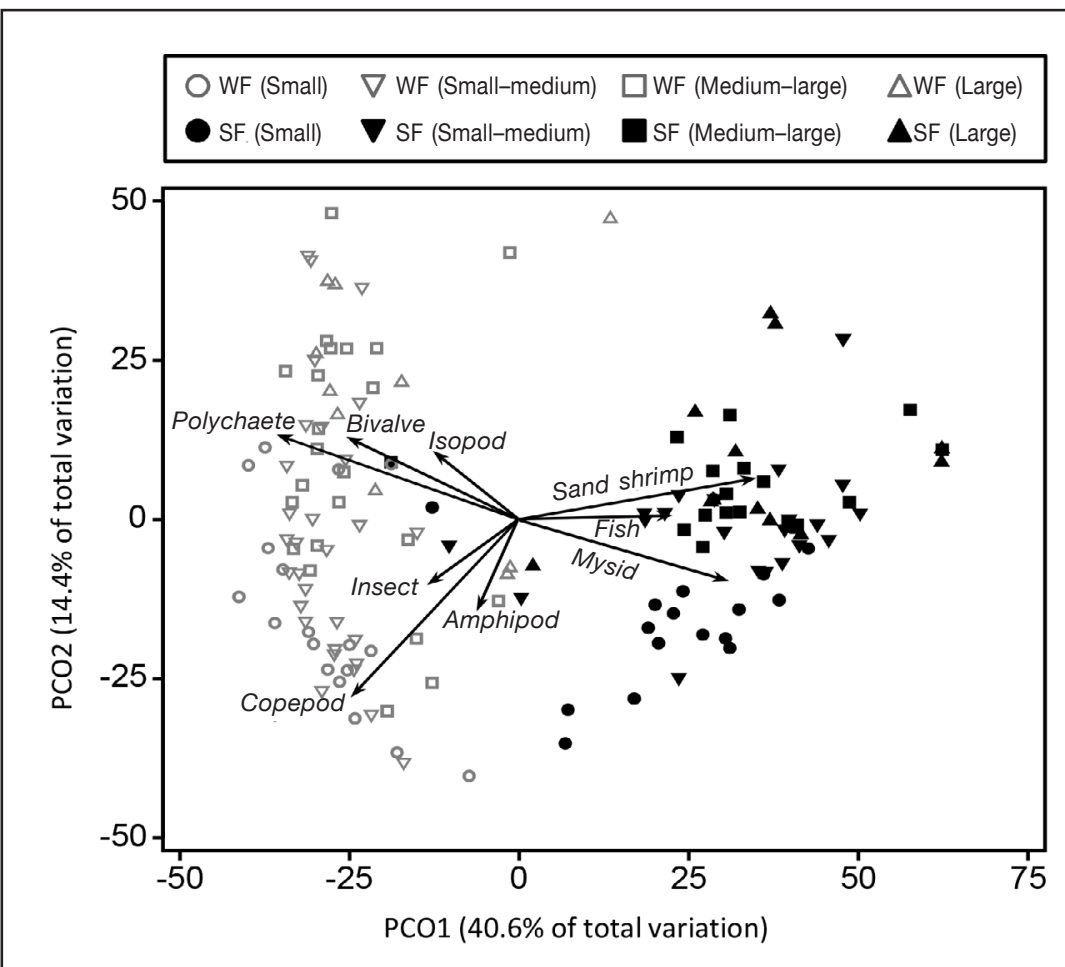

Figure 8

Biplot from principal coordinate analysis (PCO) that represents the dissimilarities in diet of winter flounder (Pseudopleuronectes americanus; WF) and summer flounder (Paralichthys dentatus; SF) as a function of species type and size class (winter and summer flounder, respectively: small, $\leq 39 \mathrm{~mm}$ TL and $\leq 59 \mathrm{~mm}$ TL; small-medium, 40-59 $\mathrm{mm}$ TL and 60 $79 \mathrm{~mm}$ TL; medium-large, 60-79 $\mathrm{mm}$ TL and 80-119 mm TL; and large, $\geq 80 \mathrm{~mm}$ TL and $\geq 120 \mathrm{~mm}$ TL). Arrows superimposed on the PCO biplots represent vectors of dominant prey taxa, and vectors correspond with the monotonic relationships between the dietary importance of a prey and the PCO axes. The first (PCO1) and second (PCO2) ordination axes correspond with species-type and body size, respectively, and quantify the percentage of total variation in diets of winter and summer flounder. Winter and summer flounder were collected from the Seekonk and Taunton Rivers during 2009-2015.

the upper reaches of the Seekonk and Taunton Rivers (SR1-SR2; TR1-TR2) (Fig. 4C).

\section{Discussion}

\section{Intraspecific diet composition}

This study provides a comprehensive analysis of the diet composition of age-0 winter flounder and summer flounder collected from 2 southern New England tidal rivers. Accordingly, both flounder species from this geographic area and habitat type had a generalist feeding strategy, as determined by the wide variety of prey consumed during the early juvenile life stage (33 and 32 novel prey taxa, respectively). Winter flounder fed predominantly on small crustaceans (e.g., amphipods, copepods, isopods, ostracods, and crab megalope) and soft-body prey (e.g., polychaetes, clam siphons, chironomid larvae, and nematodes). These results are consistent with previous analyses of the food habits of juvenile winter flounder across their broader geographic distribution (from Newfoundland to Maryland: Stehlik and Meise, 2000, and references therein; Vivian et al., 2000; Shaheen et al., 2001; Link et al., 2002; Meng et al., 2008). Summer flounder also consumed a diverse range of crustaceans (e.g., shrimps, amphipods, copepods, cumaceans, and ostracods) and soft-tissue prey (e.g., polychaetes and clam siphons), as well as 8 identifiable fish species. To the knowledge of the authors, this is the first description of the feeding habits of juvenile summer flounder from southern New England nurseries and, more specifically, from oligomesohaline tidal rivers (mean salinity <20). 
The diet of summer flounder described herein corroborate observations from the Middle and South Atlantic Bight (Packer et al., 1999); although geographic differences in conspecific diets are also apparent and are likely due to large-scale spatial variations in prey assemblages. For example, in the Chesapeake Bay, Virginia, mysid shrimp (Neomysis spp.), sand shrimp, mantis shrimp (Squilla empusa), and fish (bay anchovy [Anchoa mitchilli] and weakfish [Cynoscion regalis]) accounted for $\sim 91 \%$, by weight, of the total diet of summer flounder 125-224 mm TL (Latour et al., 2008). In the York River, a major tributary of the Chesapeake Bay, mysid shrimp (N. americana), palaemonid shrimp, and fish were the favored prey of summer flounder 98-192 mm TL (TL converted from standard length [SL]; Able and Fahay, 1998) (Smith et al., 1984). Summer flounder 100-200 mm TL collected from the Pamlico Sound, North Carolina, similarly ate a large volume of mysid shrimp $(\% V=42 \% ; N$. americana), fish (38\%; engraulids and sciaenids), and decapod shrimps (8\%; carideans and penaeids) (Powell and Schwartz, 1979). Conversely, in the polyhaline regions of the Newport and North Rivers, North Carolina (mean salinity: 31-32), the dominant prey of summer flounder $25-73 \mathrm{~mm}$ TL (TL converted to SL) were spionid polychaetes and invertebrate parts (e.g., clam siphons), which together composed $~ 90 \%$ of the total IRI $(\% I R I=\% N \times \% F$; Burke, 1995). Interestingly, the diet composition of equivalent-size southern flounder (Paralichthys lethostigma), which occupied the lower salinity portions of Newport and North Rivers (mean salinity <25), was indicative of the diet of summer flounder examined in this study, in that amphipods (Gammarus spp.) and mysid shrimp (N. americana and Americamysis bigelowi) were the most important prey categories for this congener species (combined \%IRI: 90\%; Burke, 1995).

\section{Intraspecific diet diversity and niche breadth}

Despite the evidence that winter flounder and summer flounder are feeding generalists (i.e., according to cumulative prey taxa consumed), this study also revealed that certain prey contributed disproportionately to the diet of each species. Three prey taxa specifically accounted for $>85 \%$ of the overall diet of both species: amphipods, copepods, and polychaetes (combined \%IRI: $\sim 88 \%$ ) for winter flounder and mysid shrimp, sand shrimp, and amphipods (combined \%IRI: 86\%) for summer flounder. The inequitable dietary contributions of these favored prey were reflected in the $B$ (values $\leq 0.4$ ), where low values indicated specialized feeding behavior (Levins, 1968; Novakowski et al., 2008).

Although winter and summer flounder generally are considered opportunistic feeders (Packer et al., 1999; Pereira et al., 1999), there are previous accounts of these species selectively foraging on prey that are in low abundance (Carlson et al., 1997; Shaheen et al., 2001; Latour et al., 2008; Meng et al., 2008). It is important to reiterate, however, that food niche breadth of winter and summer flounder was predator-size dependent, such that a moderate to high degree of diet diversity was observed in larger juveniles ( $>75$ and $115 \mathrm{~mm}$ TL, respectively). The broadening of dietary breadth with increasing lengths of winter and summer flounder is attributed to the concomitant enlargement of mouth gape and improved prey detection and capture abilities in larger fish (Mulkana, 1966; Manderson et al., 2000; Stehlik and Meise, 2000; Vivian et al., 2000). Further, as observed in winter flounder, spatially explicit variations in niche breadth may be a reflection of site-specific patterns in prey diversity and availability (Mulkana, 1966; Rudnick et al., 1985); for example, winter flounder have a greater niche breadth in the Taunton River because this system possibly maintains a higher abundance of novel prey.

\section{Ontogenetic and spatiotemporal effects on intraspecific diets}

Direct visual analysis of the stomach contents of winter flounder and summer flounder affirmed ontogenetic shifts in their respective diets. Winter flounder $<40 \mathrm{~mm}$ TL predominantly fed on harpacticoid and calanoid copepods, transitioning to amphipods, isopods, and bivalves with increasing size. The principal prey of summer flounder $<60 \mathrm{~mm}$ TL were mysid shrimp and copepods, whereas sand shrimp, amphipods, and fish were the dominant prey of larger conspecifics. Similar size-dependent effects on feeding habits of winter and summer flounder have been reported throughout the broader geographic distribution of each species. In the Navesink River and Sandy Hook Bay, New Jersey, for example, small winter flounder (<50 mm TL) fed mainly on copepods (calanoids and harpacticoids), small polychaetes (e.g., spionids), and amphipods (e.g., ampeliscids) (Stehlik and Meise, 2000). Subsequent increases in size (50-90 mm TL) of winter flounder resulted in a greater reliance on amphipods and a dietary switch toward larger polychaetes (e.g., nereidids), mollusks (softshell [Mya arenaria] and Nassarius spp.), and other crustaceans (mysid shrimp, sand shrimp, and isopods) (Stehlik and Meise, 2000). Comparable size-dependent patterns in feeding behavior of winter flounder were documented also in the Hudson River estuary, New York (20-65 mm TL; Vivian et al., 2000), Pettaquamscutt River, Rhode Island (10-80 mm TL; Mulkana, 1966), and Massachusetts coastal waters (<25-100 mm TL; Linton, 1921).

The diet of metamorphic summer flounder (10.4$18.2 \mathrm{~mm}$ TL, converted from SL) from the Great BayLittle Egg Harbor estuary, New Jersey, was dominated by the calanoid copepod Temora longicornis $(\% I R I=86.2 \%)$, indicating a pelagic feeding strategy (Grover, 1998). Recently settled summer flounder also forage on calanoid and harpacticoid copepods in North Carolina coastal embayments (11.5-24.7 mm TL, converted from SL; Burke, 1995) and Georgia tidal creeks (11.5-48.6 mm TL, converted from SL; Reichert and van der Veer, 1991), but the use of this prey resource 
diminished rapidly as the body size of summer flounder increased. Numerous studies have also reported the significance of mysid shrimp in the diet of juvenile summer flounder throughout the geographic range of this species (from New York to Georgia: Kimmel, 1973; Smith and Daiber, 1977; Festa ${ }^{5}$; Powell and Schwartz, 1979; Lascara, 1981; Wenner et al. ${ }^{6}$; Reichert and van der Veer, 1991; Burke, 1995; Timmons, 1995; Manderson et al., 2000; Link et al., 2002; Latour et al., 2008; Buchheister and Latour, 2011; Sagarese et al., 2011). However, the dietary contributions of mysid shrimp typically declined with the increasing size of summer flounder, and this prey resource was replaced by other macrocrustaceans (sand shrimp, mantis shrimp, and crabs), fish, and squid (Powell and Schwartz, 1979; Link et al., 2002; Latour et al., 2008; Buchheister and Latour, 2011).

Significant spatiotemporal variability was observed in the diet composition of winter and summer flounder in this study. These observed patterns may be partly attributed to differences in the size structure of winter and summer flounder across riverine sites and to progressive increases in body size over time (Taylor et al., 2016) - the latter resulting in ontogenetic dietary shifts, as described above. Alternatively, the observed food habits of winter and summer flounder may reflect habitat and seasonal variations in prey composition (Rudnick et al., 1985; Meng et al., 2008), which have previously been reported to affect the diet of both species (Mulkana, 1966; Burke, 1995; Manderson et al., 2000; Stehlik and Meise, 2000; Latour et al., 2008). Spatiotemporal variations in prey assemblages were not assessed in this study; however, prior investigations in the Narragansett Bay have revealed substantial changes in abundances of benthic meiofauna and macrofauna across sites and seasons (Rudnick et al., 1985; Calabretta and Oviatt, 2008), and some of these fauna constitute important prey for juvenile winter and summer flounder (e.g., harpacticoid copepods, polychaetes, nematodes, and bivalves).

\section{Interspecific dietary overlap}

The feeding habits of winter flounder and summer flounder differed significantly from each other, but the extent of dietary overlap was affected by their respective body sizes. According to assessments with the Schoener index, there was minimal dietary overlap of flounder species when comparisons were made independent of body size $(\alpha<0.4$; Hartman and Brandt,

\footnotetext{
${ }^{5}$ Festa, P. J. 1979. Analysis of the fish forage base of the Little Egg Harbor estuary. N.J. Dep. Environ. Prot., Tech. Rep. 24M, 134 p. [Available from website.]

${ }^{6}$ Wenner, C. A., W. A. Roumillat, J. E. Moran Jr., M. B. Maddox, L. B. Daniel III, and J. W. Smith. 1990. Investigations on the life history and population dynamics of marine recreational fishes in South Carolina: part 1, 177 p. Mar. Resour. Res. Inst., S. C. Wildl. Mar. Res. Dep., Charleston, SC.
}

1995; Novakowski et al., 2008; Zahn Seegert et al., 2014) — a finding that indicated food niche segregation. For winter and summer flounder of equivalent sizes, however, dietary overlap was inversely related to total length. Moderate to high resource overlap occurred among small winter and summer flounder $(<40 \mathrm{~mm}$ TL) and was attributed to their mutual reliance on copepods and, to a lesser extent, amphipods. Ontogenetic dietary shifts exhibited by winter and summer flounder then resulted in notable deviations in their food habits, although amphipods remained a common prey among larger individuals (up to $85 \mathrm{~mm} \mathrm{TL}$ ).

Multiple species of flatfish often coexist in nursery habitats as juveniles (Burke, 1995; Rooper et al., 2006; Nissling et al., 2007; Mariani et al., 2011), leading to potential interspecific competition (Złoch and Sapota, 2010). Niche overlap is typically minimized, however, because of differences in prey preferences (i.e., biological or diet segregation) or fine-scale distribution patterns within the nursery (i.e., physical or spatiotemporal segregation), the latter in response to heterogeneous environmental conditions (Burke, 1995; Rooper et al., 2006; Mariani et al., 2011). Moreover, occurrences of significant dietary overlap of flatfish species do not necessarily result in competitive interactions, given that the foraging rates of most juvenile flatfish are insufficient to reduce prey abundances to levels that are biologically limiting (Kuipers, 1977; Evans, 1983; Shaw and Jenkins, 1992).

In this study, resource partitioning did not occur through spatiotemporal segregation, considering that $\sim 84 \%$ of the seine hauls that collected summer flounder also yielded winter flounder. Alternatively, the relatively low degree of dietary overlap of flounder species was attributed to interspecific differences in prey preferences, and dietary differences were most evident at larger body sizes of winter and summer flounder. The diet segregation between winter and summer flounder may also be explained by differences in their respective feeding morphologies. Summer flounder have a relatively large mouth with canine-like teeth (Woolcott et al., 1968), which enables the capturing and processing of larger prey items (Manderson et al., 2000). In contrast, the small mouth and reduced gape size of winter flounder imposes morphological constraints on their diet, which is limited to small-body prey throughout their development (Stehlik and Meise, 2000; Vivian et al., 2000).

This study does provide some evidence of significant dietary overlap for small winter and summer flounder ( $<40 \mathrm{~mm}$ TL); yet it is hypothesized that the abundances of either flounder species did not attain levels where interference or exploitative competition could cause the limitation of food resources (Evans, 1983; Modin and Pihl, 1994; Iles and Beverton, 2000; Taylor et al., 2016). Accordingly, the failed recovery of winter flounder in southern New England habitats, including the Narragansett Bay and contiguous waters (Collie et al., 2008; $\mathrm{NEFSC}^{2}$ ), does not appear to be associated with putative competition with juvenile summer flounder. 


\section{Acknowledgments}

We are grateful to B. Bourque and numerous undergraduate research assistants (Roger Williams University [RWU], Bristol, Rhode Island) for their efforts in field sampling and stomach content analysis. We also thank S. Pratt (University of Rhode Island, Kingston, Rhode Island) for assisting with the identification of polychaetes recovered from stomachs of winter and summer flounder. This project was supported in part by the Rhode Island National Science Foundation Experimental Program to Stimulate Competitive Research, the Rhode Island Science and Technology Advisory Council Research Alliance Collaborative Grant, the RWU Foundation to Promote Scholarship Grant, and by Award P20RR016457 from the National Institutes of Health National Center for Research Resources. The content is solely the responsibility of the authors and does not necessarily represent the official views of the National Center for Research Resources or the National Institutes of Health.

\section{Literature cited}

Able, K. W., and M. P. Fahay.

1998. The first year in the life of estuarine fishes in the Middle Atlantic Bight, 342 p. Rutgers Univ. Press, New Brunswick, NJ.

Anderson, M. J., R. N. Gorley, and K. R. Clarke.

2008. PERMANOVA+ for PRIMER: guide to software and statistical methods, 214 p. PRIMER-E Ltd., Plymouth, UK.

Bailey, K. M.

1994. Predation on juvenile flatfish and recruitment variability. Neth. J. Sea Res. 32:175-189. Article

Bogstad, B., M. Pennington, and J. H. Vølstad.

1995. Cost-efficient survey designs for estimating food consumption by fish. Fish. Res. 23:37-46. Article

Buchheister, A., and R. J. Latour.

2011. Trophic ecology of summer flounder in lower Chesapeake Bay inferred from stomach content and stable isotope analyses. Trans. Am. Fish. Soc. 140:1240-1254. Article

Buckel, J. A., M. J. Fogarty, and D. O. Conover.

1999. Foraging habits of bluefish, Pomatomus saltatrix, on the U.S. east coast continental shelf. Fish. Bull. 97:758-775.

Burke, J. S.

1995. Role of feeding and prey distribution of summer and southern flounder in selection of estuarine nursery habitats. J. Fish Biol. 47:355-366. Article

Calabretta, C. J., and C. A. Oviatt.

2008. The response of benthic macrofauna to anthropogenic stress in Narragansett Bay, Rhode Island: a review of human stressors and assessment of community conditions. Mar. Pollut. Bull. 56:1680-1695. Article

Carlson, J. K., T. A. Randall, and M. E. Mroczka. 1997. Feeding habits of winter flounder (Pleuronectes americanus) in a habitat exposed to anthropogenic disturbance. J. Northwest Atl. Fish. Sci. 21:65-73.

Chambers, R. C., and W. C. Leggett. 1987. Size and age at metamorphosis in marine fishes: an analysis of laboratory-reared winter flounder (Pseudopleuronectes americanus) with a review of variation in other species. Can. J. Fish. Aquat. Sci. 44:19361947. Article

Clarke, K. R., R. N. Gorley, P. J. Somerfield, and R. M. Warwick. 2014. Change in marine communities: an approach to statistical analysis and interpretation, $3^{\text {rd }}$ ed., $260 \mathrm{p}$. PRIMER-E Ltd., Plymouth, UK.

Collie, J. S., A. D. Wood, and H. P. Jeffries.

2008. Long-term shifts in the species composition of a coastal fish community. Can. J. Fish. Aquat. Sci. 65:1352-1365. Article

Cortés, E.

1997. A critical review of methods of studying fish feeding based on analysis of stomach contents: application to elasmobranch fishes. Can. J. Fish. Aquat. Sci. 54:726-738. Article

DeLong, A. K., J. S. Collie, C. J. Meise, and J. C. Powell.

2001. Estimating growth and mortality of juvenile winter flounder, Pseudopleuronectes americanus, with a lengthbased model. Can. J. Fish. Aquat. Sci. 58:2233-2246. Article

Evans, S.

1983. Production, predation and food niche segregation in a marine shallow soft-bottom community. Mar. Ecol. Prog. Ser. 10:147-157.

Grover, J. J.

1998. Feeding habits of pelagic summer flounder, Paralichthys dentatus, larvae in oceanic and estuarine habitats. Fish. Bull. 96:248-257.

Hansson, S.

1998. Methods of studying fish feeding: a comment. Can. J. Fish. Aquat. Sci. 55:2706-2707. Article

Hart, R. K., M. C. Calver, and C. R. Dickman.

2002. The index of relative importance: an alternative approach to reducing bias in descriptive studies of animal diets. Wildl. Res. 29:415-421. Article

Hartman, K. J., and S. B. Brandt.

1995. Trophic resource partitioning, diets, and growth of sympatric estuarine predators. Trans. Am. Fish. Soc. 124:520-537. Article

Hyslop, E. J.

1980. Stomach contents analysis-a review of methods and their application. J. Fish Biol. 17:411-429. Article

Iles, T. C., and R. J. H. Beverton.

2000. The concentration hypothesis: the statistical evidence. ICES J. Mar. Sci. 57:216-227. Article

Jeffries, H. P., and M. Terceiro.

1985. Cycle of changing abundances in the fishes of the Narragansett Bay area. Mar. Ecol. Prog. Ser. 25:239244.

Karlson, A. M. L., G. Almqvist, K. E. Skóra, and M. Appelberg. 2007. Indications of competition between non-indigenous round goby and native flounder in the Baltic Sea. ICES J. Mar. Sci. 64:479-486. Article

Keller, A. A., and G. Klein-MacPhee.

2000. Impact of elevated temperature on the growth, survival, and trophic dynamics of winter flounder larvae: a mesocosm study. Can. J. Fish. Aquat. Sci. 57:2382-2392. Article

Kimmel, J. J.

1973. Food and feeding of fishes from Magothy Bay, Virginia. M.S. thesis, 190 p. Old Dominion Univ., Norfolk, VA. 
Kuipers, B. R.

1977. On the ecology of juvenile plaice on a tidal flat in the Wadden Sea. Neth. J. Sea Res. 11:56-91. Article

Lascara, J.

1981. Fish predator-prey interactions in areas of eelgrass (Zostera marina). M.S. thesis, 81 p. Coll. William Mary, Williamsburg, VA.

Latour, R. J., J. Gartland, C. F. Bonzek, and R. A. Johnson. 2008. The trophic dynamics of summer flounder (Paralichthys dentatus) in Chesapeake Bay. Fish. Bull. 106: 47-57.

Levins, R.

1968. Evolution in changing environments: some theoretical explorations, 132 p. Princeton Univ. Press, Princeton, NJ.

Liao, H., C. L. Pierce, and J. G. Larscheid.

2001. Empirical assessment of indices of prey importance in the diets of predacious fish. Trans. Am. Fish. Soc. 130:583-591. Article

Link, J. S., K. Bolles, and C. G. Milliken.

2002. The feeding ecology of flatfish in the Northwest Atlantic. J. Northwest Atl. Fish. Sci. 30:1-17.

Linton, E.

1921. Food of young winter flounders. Appendix IV to the Report of the U.S. Commissioner of Fisheries for 1921. Bur. Fish. Doc. 907, 14 p.

Malloy, K. D., and T. E. Targett.

1991. Feeding, growth and survival of juvenile summer flounder Paralichthys dentatus: experimental analysis of the effects of temperature and salinity. Mar. Ecol. Prog. Ser. 72:213-223.

Manderson, J. P., B. A. Phelan, A. W. Stoner, and J. Hilbert.

2000. Predator-prey relations between age-1+ summer flounder (Paralichthys dentatus, Linnaeus) and age-0 winter flounder (Pseudopleuronectes americanus, Walbaum): predator diets, prey selection, and effects of sediments and macrophytes. J. Exp. Mar. Biol. Ecol. 251:17-39. Article

Mariani, S., C. Boggan, and D. Balata.

2011. Food resource use in sympatric juvenile plaice and flounder in estuarine habitats. Mar. Ecol. 32:96-101. Article

Meng, L., D. L. Taylor, J. Serbst, and J. C. Powell.

2008. Assessing habitat quality of Mount Hope Bay and Narragansett Bay using growth, RNA:DNA, and feeding habits of caged juvenile winter flounder (Pseudopleuronectes americanus Walbaum). Northeast. Nat. 15:35-56. Article

Modin, J., and J. Pihl.

1994. Differences in growth and mortality of juvenile plaice, Pleuronectes platessa L., following normal and extremely high settlement. Neth. J. Sea Res. 32:331-341. Article

Mulkana, M. S.

1966. Habitats of juvenile fishes in two Rhode Island estuaries. Gulf Res. Rep. 2:97-167. Article

Nissling, A., M. Jacobsson, and N. Hallberg.

2007. Feeding ecology of juvenile turbot Scophthalmus maximus and flounder Pleuronectes flesus at Gotland, Central Baltic Sea. J. Fish Biol. 70:1877-1897. Article

Novakowski, G. C., N. S. Hahn, and R. Fugi.

2008. Diet seasonality and food overlap of the fish assemblage in a pantanal pond. Neotrop. Ichthyol. 6:567-576. Article
Nye, J. A., J. S. Link, J. A. Hare, and W. J. Overholtz.

2009. Changing spatial distribution of fish stocks in relation to climate and population size on the northeast United States continental shelf. Mar. Ecol. Prog. Ser. 393:111-129. Article

Packer, D. B., S. J. Griesbach, P. L. Berrien, C. A. Zetlin, D. L. Johnson, and W. W. Morse.

1999. Essential fish habitat source document: summer flounder, Paralichthys dentatus, life history and habitat characteristics. NOAA Tech. Memo. NMFS-NE-151, 88 p.

Pearcy, W. G.

1962. Ecology of an estuarine population of winter flounder, Pseudopleuronectes americanus (Walbaum), parts IIV. Bull. Bingham Oceanogr. Collect. 18, 78 p.

Pereira, J., R. Goldberg, J. J. Ziskowski, P. L. Berrien, W. W. Morse, and D. L. Johnson.

1999. Essential fish habitat source document: winter flounder, Pseudopleuronectes americanus, life history and habitat characteristics. NOAA Tech. Memo. NFMSNE-138, 39 p.

Powell, A. B., and F. J. Schwartz.

1979. Food of Paralichthys dentatus and P. lethostigma (Pisces: Bothidae) in North Carolina estuaries. Estuaries 2:276-279.

Reichert, M. J. M., and H. W. van der Veer.

1991. Settlement, abundance, growth and mortality of juvenile flatfish in a subtropical tidal estuary (Georgia, U.S.A.). Neth. J. Sea Res. 27:375-391. Article

Rooper, C. N., D. R. Gunderson, and D. A. Armstrong.

2006. Evidence for resource partitioning and competition in nursery estuaries by juvenile flatfish in Oregon and Washington. Fish. Bull. 104:616-622.

Rudnick, D. T., R. Elmgren, and J. B. Frithsen.

1985. Meiofaunal prominence and benthic seasonality in a coastal marine ecosystem. Oecologia 67:157168. Article

Sagarese, S. R., R. M. Cerrato, and M. G. Frisk.

2011. Diet composition and feeding habits of common fishes in Long Island Bays, New York. Northeast. Nat. 18:291-314. Article

Schoener, T. W.

1974. Resource partitioning in ecological communities. Science 185:27-39. Article

Shaheen, P. A., L. L. Stehlik, C. J. Meise, A. W. Stoner, J. P. Manderson, and D. L. Adams.

2001. Feeding behavior of newly settled winter flounder (Pseudopleuronectes americanus) on calanoid copepods. J. Exp. Mar. Biol. Ecol. 257:37-51. Article

Shaw, M., and G. P. Jenkins.

1992. Spatial variation in feeding, prey distribution and food limitation of juvenile flounder Rhombosolea tapirina Günther. J. Exp. Mar. Biol. Ecol. 165:1-21. Article

Smith, R. W., and F. C. Daiber.

1977. Biology of the summer flounder, Paralichthys dentatus, in Delaware Bay. Fish. Bull. 75:823-830.

Smith, S. M., J. G. Hoff, S. P. O’Neil, and M. P. Weinstein.

1984. Community and trophic organization of nekton utilizing shallow marsh habitats, York River, Virginia. Fish. Bull. 82:455-467.

Smith, L. M, S. Whitehouse, and C. A. Oviatt.

2010. Impacts of climate change on Narragansett Bay. Northeast. Nat. 17:77-90. Article 
Stehlik, L. L., and C. J. Meise.

2000. Diet of winter flounder in a New Jersey estuary: ontogenetic change and spatial variation. Estuaries 23:381-391.

Taylor, D. L., and J. S. Collie.

2003a. A temperature- and size-dependent model of sand shrimp (Crangon septemspinosa) predation on juvenile winter flounder (Pseudopleuronectes americanus). Can. J. Fish. Aquat. Sci. 60:1133-1148. Article

2003b. Effect of temperature on the functional response and foraging behavior of the sand shrimp Crangon septemspinosa preying on juvenile winter flounder Pseudopleuronectes americanus. Mar. Ecol. Prog. Ser. 263:217-234. Article

Taylor, D. L., J. McNamee, J. Lake, C. L. Gervasi, and D. G. Palance.

2016. Juvenile winter flounder (Pseudopleuronectes americanus) and summer flounder (Paralichthys dentatus) utilization of southern New England nurseries: comparisons among estuarine, tidal river, and coastal lagoon shallowwater habitats. Est. Coasts 39:1505-1525. Article

Timmons, M.

1995. Relationships between macroalgae and juvenile fishes in the inland bays of Delaware. Ph.D. diss., $155 \mathrm{p}$. Univ. Delaware, Newark, DE. Article
Ustups, D., U. Bergström, A. B. Florin, E. Kruze, D. Zilniece, D. Elferts, E. Knospina, and D. Uzars.

2016. Diet overlap between juvenile flatfish and the invasive round goby in the central Baltic Sea. J. Sea Res. 107(Part 1):121-129. Article

Vivian, D. H., J. T. Duffy-Anderson, R. G. Arndt, and K. W. Able.

2000. Feeding habits of young-of-the-year winter flounder, Pseudopleuronectes americanus, in the New York-New Jersey Harbor estuary, USA. Bull. N.J. Acad. Sci. 45:1-6.

Woolcott, W. S., C. Beirne, and W. M. Hall Jr.

1968. Descriptive and comparative osteology of the young of three species of flounder, genus Paralichthys. Chesap. Sci. 9:109-120. Article

Zahn Seegert, S. E., E. J. Rosi-Marshall, C. V. Baxter, T. A. Kennedy, R. O. Hall Jr., and W. F. Cross.

2014. High diet overlap between native small-bodied fishes and nonnative fathead minnow in the Colorado River, Grand Canyon, Arizona. Trans. Am. Fish. Soc. 143:10721083.

Złoch, I., and M. R. Sapota.

2010. Trophic interactions between preadult and adult Pomatoschistus minutus and Pomatoschistus microps and young Platichthys flesus occurring in inshore waters of the Gulf of Gdańsk (Southern Baltic). Oceanol. Hydrobiol. Stud. 39:37-53. Article 